\title{
Synergic estimation of columnar integrated aerosol properties and their vertical resolved profiles in respect to the scenarios of dust intrusions over Granada
}

\author{
Florian Mandija ${ }^{\text {a, b, * }}$, Juan Luis Guerrero-Rascado ${ }^{\text {b, c }}$, Hassan Lyamani ${ }^{\text {b, c }}$, \\ María Jos'e Granados-Mun oz b, c, Lucas Alados-Arboledas b, c \\ a Dpt. Physics, Faculty of Natural Sciences, University of Shkodra, Shkoder, Albania \\ ${ }^{\mathrm{b}}$ Andalusian Institute for Earth System Research (IISTA-CEAMA), Granada, Spain \\ c Dpt. Applied Physics, University of Granada, Granada, Spain
}

h i g h l i g h t s

- Columnar and vertical-resolved aerosol optical properties during dust events in Granada, Spain are investigated.

- Analyses are based on the AERONET and EARLINET data and Hysplit back-trajectories.

- Six different scenarios of Saharan dust intrusions were found overpassing Granada.

- Aerosol characteristics according to these scenarios are determined.

a r ticle i n f o

Article history:

Received 10 May 2016

Received in revised form

19 September 2016

Accepted 20 September 2016

Available online 23 September 2016

Keywords:

Dust intrusion scenarios Aerosol optical properties

Sunphotometer and lidar measurements

https://doi.org/10.1016/j.atmosenv. 2016.09 .045 a b s t r a c t

In this paper, we present a study of the columnar and vertically resolved aerosol optical properties over Granada (Spain) during dust events detected during July-August in the period 2012e2013. For this purpose, we classified the events according to their origins and pathways. The analyzed aerosol properties include; columnar aerosol optical properties like aerosol optical depth (AOD) and Angstrom exponent (AE), as well as the lidar products, like backscatter-related Angstrom exponent and linear particle depolarization ratio (LDPR). The lidar profiles are used for determination of the geometrical structure of dust layers and the aerosol optical parameters inside dust layers.

There are identified 58 dusty days over Granada during the periods July-August, 2012e2013. In 71\% of the dust, event analyzed the dust plume over Granada is located between 3000 and $4000 \mathrm{~m}$ a.g.l. Mean values of AOD500 according to the Atlantic and Mediterranean pathway were 0.28 0.10 and 0.93 \pm 0.17 . Meanwhile, the mean values of $\mathrm{AE} 440-870$ were $0.57 \pm 0.25$ and $0.43 \pm 0.20$. Three region are identified as the main dust sources affecting the dust intrusions over Granada. Two principal pathways of air masses during dust intrusion over Granada were observed: through Atlantic (52.7\%) and through Mediterranean (47.3\%). Air masses which come through the Mediterranean present larger AOD and lower Angstrom exponent values than those air masses coming through Atlantic.

Lidar measurements show different vertical distributions on particle backscatter coefficient, during different scenarios of dust intrusions. The lidar profiles indicate that average base and top heights of all dust during the investigation period were $2.1 \pm 0.7$ and $4.8 \pm 0.9 \mathrm{~km}$, and their center of mass and thickness were $3.3 \pm 0.7$ and $2.8 \pm 1.0 \mathrm{~km}$ a.g.l. The AE355/532 profiles for the dust intrusions present some differences depending on the source regions and path followed by the dust. On the other hand, the profiles of LPDRat $532 \mathrm{~nm}$ were more similar for all scenarios. 
1. Introduction

Atmospheric aerosols play an important role in global radiation budget (IPCC, 2013). However, their concentrations are very variable in the troposphere due to the variability of their sources and the strong influence of the meteorological conditions. According to the Fifth Report of the Inter-governmental Panel on Climate Change (IPCC, 2013), the lack of adequate information on aerosol temporal and spatial variability causes high uncertainty on their influence on the global radiation budget compared to the gasses effect. To improve the knowledge on climate change, it is very important to reduce these uncertainties. Furthermore, atmospheric aerosol particles can interact with clouds influencing the Earth's climate indirectly. Thus, aerosol particles modify microphysical properties of clouds, acting as cloud condensation nuclei, influencing on the precipitations (Rosenfeld et al., 2001). Depending on the temperature and their type, aerosol particles can act as well as ice nuclei (Sassen, 2002; Zuberi et al., 2002). Atmospheric aerosols have also effects on air quality and, thus, on the human health (Pope et al., 2002; Miller et al., 2007).

Each year, an estimated $2000 \mathrm{Mt}$ dust is emitted into the atmosphere, 75\% of which is deposited to the continents (Shao et al., 2011). Desert dust represents about $40 \%$ of aerosol loading into the troposphere and about half of this is attributed to the Sahara desert. On the global scale, the Sahara desert is the principal source of mineral dust (Liu et al., 2008; Tegen and Schepanski, 2009). Dust particles can travel very long distances and the arrival of dust plumes to the Mediterranean region is a common feature (Engelstaedter et al., 2006; Sunnu et al., 2008; Hamonou et al., 1999; Ansmann et al., 2003; Papayannis et al., 2008; Toledano et al., 2011). After the long-range transport, the aging of the dust and the mixing with other aerosol types modify the optical properties of the desert dust (Hand et al., 2010; Bauer et al., 2011). Many investigations about the Saharan dust intrusions over the Mediterranean were carried out during the last decades (Di Sarra et al., 2001; Prospero et al., 2002; Israelevich et al., 2003; GuerreroRascado et al., 2008, 2009; Preißler et al., 2011; Valenzuela et al., 2012a; Córdoba-Jabonero et al., 2011; Navas-Guzman et al., 2013). The Saharan dust is a key factor in the aerosol concentrations over the Mediterranean basin (e.g., Barnaba and Gobbi, 2004; Pey et al., 2013). The Saharan Desert is also the principal source of dust events over the Iberian Peninsula (Lyamani et al., 2005; Cachorro et al., 2008; Guerrero-Rascado et al., 2008). In this sense, Granada is affected by dust intrusions mostly during the summer season (Valenzuela et al., 2012a; Córdoba-Jabonero et al., 2011; Navaz-Guzman, 2012).

Passive remote sensing techniques (Sun photometry), give column integrated values of several aerosol optical and microphysical properties, like aerosol optical depth (AOD), Angstrom exponent (AE), fine mode fraction (FMF), coarse mode contribution to AOD (CM_AOD) and single scattering albedo among others (Eck et al., 1999; Perez et al., 2006). However, these techniques do not provide vertically-resolved variables. This is an important limitation of these techniques. Profiles can be obtained using active remote sensing techniques. The vertical-resolved aerosol optical properties are analyzed using the lidar 
measurements (Mattis et al., 2004; Mathias et al., 2004b; Muller et al., 2004). Aerosol profiling with high time and space resolution is a valuable tool to study the vertical aerosol structures and their evolution (Pappalardo et al., 2010). Other tools to analyze the dust events are the satellite products, like maps of MODIS (Moderate Resolution Imaging Spectroradiometer), etc. Satellite products provide nonintrusive measurements and global coverage (Kaufman et al., 1994; King et al., 1999; Kahn et al., 2005; Remer et al., 2005). However, satellite measurements present low temporal resolution. Additional tools, which permit to forecast dust intrusions, are the models, like HYSPLIT4 (HYbrid Single Particle Lagrangian Integrated Trajectory model), BSC-DREAM 8b.v2.0 (Dust Regional Atmospheric Model), NAAPS (Navy Aerosol Analysis and Prediction System), (Draxler and Rolph, 2003; Nickovic et al., 2001; Christensen, 1997), etc.

In this paper, dust intrusions over Granada are analyzed. We have focused our analyses on two successive summer seasons, covering the period July-August. We have not included September in our analysis, because of a relatively low number of available lidar data during this month. In this study, we focus on the characterization of the aerosol optical properties, measured during these dust events. For this purpose, we analyzed the backscatter-related Angstrom exponent and linear particle depolarization ratio inside the dust layers as well as the geometrical structures of dust layers, like base and top heights, as well as their backscatter-weighted altitude and the layer thickness. In addition, an statistical analyses of the different aerosol properties have been done after classifying the dust events into different scenarios. These analyses give detailed information about the characteristics of dust events over Granada during these summer sessions.

The paper has the following structure: The descriptions of the experimental site and instrumentation are given in Sect.2. In Sect.3, we present the method of classification of air masses during dust events in Granada. Later, in Sect.4, we present the results and an in-depth analysis of desert dust characteristics over Granada measured by sunphotometer and lidar. Sect.5 presents the concluding remarks.

\section{Experimental site and instrumentation measurements}

Data presented in this study were collected at the Andalusian Centre for Environmental Research CEAMA, located in the city of Granada (Spain, $37.16^{\circ} \mathrm{N}, 3.61^{\circ} \mathrm{W}, 680 \mathrm{~m}$ a.s.l.). Granada is a nonindustrialized medium-sized city, with a population of 250,000 inhabitants (350,000 including the metropolitan area). Mountains surround the city with elevations between 1000 and $3500 \mathrm{~m}$ a.s.l. The study area is about $200 \mathrm{~km}$ away from the African continent and approximately $50 \mathrm{~km}$ away from the western Mediterranean basin. Two major aerosol source regions; Europe and North Africa affect Granada. Europe is the major source of anthropogenic pollutants, and North Africa is the principal source of mineral dust affecting Iberian Peninsula (Alados-Arboledas et al., 2003; Lyamani et al., 2006a, 2010; Perez-Ramirez et al., 2012; Titos et al., 2012). Due to its proximity to the Iberian Peninsula, North Africa constitutes a potential source of mineral particles under certain meteorological scenarios (Rodriguez et al., 2001; Escudero et al., 2006). Moreover, the Mediterranean basin represents an additional source of 
atmospheric aerosol (Alados-Arboledas et al., 2003, 2008; Lyamani et al., 2004,

$\underline{2005}$, 2006b, 2010; Guerrero-Rascado et al., 2008, 2009; Valenzuela et al., 2012a, b). Usually, high temperatures and low humidity in summer induce numerous forest fires in the Iberian Peninsula, whose smoke represents an additional source of atmospheric aerosol. The near-continental conditions prevailing at this site are responsible for large seasonal temperature differences, providing cool winters and hot summers.

Daytime, column-integrated characterization of the atmospheric aerosol was performed using a sunphotometer CE-318-4 included in the AERONET (Aerosol Robotic Network) network (Holben et al., 1998). The measurements are performed in regular basis during the working days. This Sun photometer makes direct sun measurements every $15 \mathrm{~min}$ with a $1.2^{\circ}$ full field of view at 340, 380, 440, 500, 675, 870,940 and $1020 \mathrm{~nm}$. The full-width at half-maximum of the interference filters are $2 \mathrm{~nm}$ at $340 \mathrm{~nm}$, $4 \mathrm{~nm}-380 \mathrm{~nm}$ and $10 \mathrm{~nm}$ at all other wavelengths. Solar extinction measurements are used to obtain aerosol optical depth at each wavelength except at $940 \mathrm{~nm}$, which is used to retrieve total column water vapor. Calibration of this instrument is performed under AERONET standards.

Aerosol vertical profiling was performed using a multiwavelength Raman lidar model LR331D400 (Raymetrics S.A., Greece). It is configured in a monostatic biaxial alignment pointing vertically to the zenith and based on a pulsed Nd:YAG laser at $1064 \mathrm{~nm}$ (110 mJ), $532 \mathrm{~nm}$ (65 mJ) and $355 \mathrm{~nm}$ (60 mJ) simultaneously, firing laser shots with a repetition rate of $10 \mathrm{~Hz}$. The receiving system is a Cassegrainian telescope and a wavelength separation unit that consists of dichroic mirrors, interferential filters, and a polarization cube. Detection is carried out in seven channels corresponding to elastic wavelengths at $1064 \mathrm{~nm}, 532 \mathrm{~nm}$ (parallel- and perpendicular-polarized) and $355 \mathrm{~nm}$, and to inelastic wavelengths at 607 nm (nitrogen Raman-shifted signal excited by radiation at 532 nm), 387 nm (nitrogen Raman-shifted signal excited by radiation at $355 \mathrm{~nm}$ ) and $408 \mathrm{~nm}$ (water-vapour Raman-shifted signal excited by radiation at $355 \mathrm{~nm}$ ). The system presents depolarization capabilities at $532 \mathrm{~nm}$ (532-cross and 532parallel detection channels), which allows the retrievals of particle linear depolarization ratio profiles $\left(\delta^{\mathrm{P}}\right)$, as described in Bravo-Aranda et al., 2013. The instrument operates with a spatial vertical resolution of $7.5 \mathrm{~m}$. Due to the instrument setup, the incomplete overlap between the laser beam and the receiver field of view limits the lowest observations (full overlap is obtained at $970 \mathrm{~m}$ above ground; Navas-Guzmán et al., 2011). Correction of the overlap effect is performed by applying the procedure previously suggested by Wandinger, and Ansmann, 2002 and Navas-Guzmán et al., Navas-Guzmán et al., 2011. Details about this instrument can be found in (Guerrero-Rascado et al., 2008, 2009). This instrument was incorporated to EARLINET- European Aerosol Research Lidar Network (Bosenberg et al., 2001) in April 2005. It has been part of the EARLINET-ASOS (Advanced Sustainable Observation System) project (http://www.earlinet.org/) and currently is included in the ACTRIS European. 
For this study, we use the regular daytime data of the lidar measurements performed in the frame of EARLINET (Pappalardo et al., 2014) together with additional measurements registered during dust events. In total, during this period are elaborated 231 lidar profiles; 145 in August and 86 in July.

\section{Identification of desert dust events}

For detecting the African desert dust intrusions over our site, we have based our analyses on AERONET daytime data. Additional tools for these determinations are the dust models such as BSC-BSC-DREAM (Nickovic et al., 2001), NAAPS (Christensen, 1997) and HYSPLIT4 back-trajectory analyses (Draxler and Rolph, 2003), as well as synoptic meteorological charts, satellite images (eg. MODIS and OMI). The numerical models generate maps showing estimations of the aerosol properties over geographical locations. The maps generated by these models are used to identify the desert dust plumes moving towards and reaching our investigated area. We have used the maps of AOD, dust surface concentration, etc. generated by BSC-DREAM and NAAPS to estimate the evolution of dust plume during the dust events over passing Granada. The evolution of the dust plumes is also tracked by satellite imagery. The MODIS Terra and Aqua have provided aerosols related parameters for the entire globe since 2000 and 2002, respectively. Thus, the MODIS instruments onboard the Terra and Aqua platforms are used for mapping of AOD in the area of interest. The satellite observations are used to detect the dust episode and identify the area affected by the plumes. The MODIS aerosol optical thickness standard product (AOD at $550 \mathrm{~nm}$ ) is employed to evaluate the AOD in the period gaps in which AERONET data are not available. Here, AOD values at $550 \mathrm{~nm}$ are provided by the MOD05_L2 and MYDO05_L2(daily, $10 \mathrm{~km}$ spatial resolution). The threshold, $\mathrm{AOD}_{550}>0.15$, is the same with the AERONET data. However, the use of these additional tools was done only in limited cases, only when the AERONET data were not available.

We used sun photometer data to confirm the presence of desert dust over our area. Days with average $\mathrm{AOD}_{500}>0.15$ and $\mathrm{AE}_{440-870}<1$ were considered as dusty days. Meanwhile, we consider that a dust event includes the consecutive days detected as dusty. These threshold values were widely used for identification of desert dust by sun photometry measurements (e.g. Kumar et al., 2014a, b; Papayannis et al., 2009; Mona et al., 2006; Valenzuela et al., 2014). Also, we used linear particle depolarization ratio at $532 \mathrm{~nm}\left(\mathrm{LPDR}_{532}\right)$ and backscatter related Angstrom exponent evaluated between 355 and $532 \mathrm{~nm}$, derived from lidar measurements to make further analyses, like the determination of their shapes inside the dust layers (Freudenthaler et al., 2009; Bravo-Aranda et al., 2013).

Air mass 120-hr backward trajectories calculated by HYSPLIT4 at different altitudes, from 1000 to 6000 a.g.l, were used to identify the source regions of desert dust observed over our study area during the analyzed period following the methodology described by Valenzuela et al. (2012b). This method assumes that the dust particles are confined to the mixed layer at the potential source region and that the air mass is loaded by desert dust when the air mass altitude is lower than or close to the altitude of the mixed layer at the potential source. Here, the HYSPLIT4 model, using a 3-hr resolution, supplied both, the air mass backward-trajectories and mixed layer altitudes. According to this criterion, three source regions were 
identified: (1) region A (northern Morocco, northwestern Algeria), (2) region B (Western Sahara, northwestern and (3) region C (eastern Algeria, Tunisia), Fig. 1. These source regions are also previously achieved (Valenzuela, 2012). Finally, we used the cluster analysis to identify the main pathways of desert dust transport to our study site. This method is based on the geometric distance between individual trajectories, and it takes into account speed and direction of the trajectory. The results are centroids, which group, individual trajectories with similar behavior of their direction. The centroid represents the average of the trajectories included in that cluster. The HYSPLIT4 model has a clustering tool based on the variations in both the total variance between clusters (TSV, Spatial Variance Total) and the variance between each component trajectory (SPVAR, Spatial Variance) (Draxler and Rolph, 2003). The cluster analysis resulted in two main pathways: African air masses arriving at Granada through the Atlantic Ocean and those reaching the study area through the Mediterranean Sea (Fig. 2).

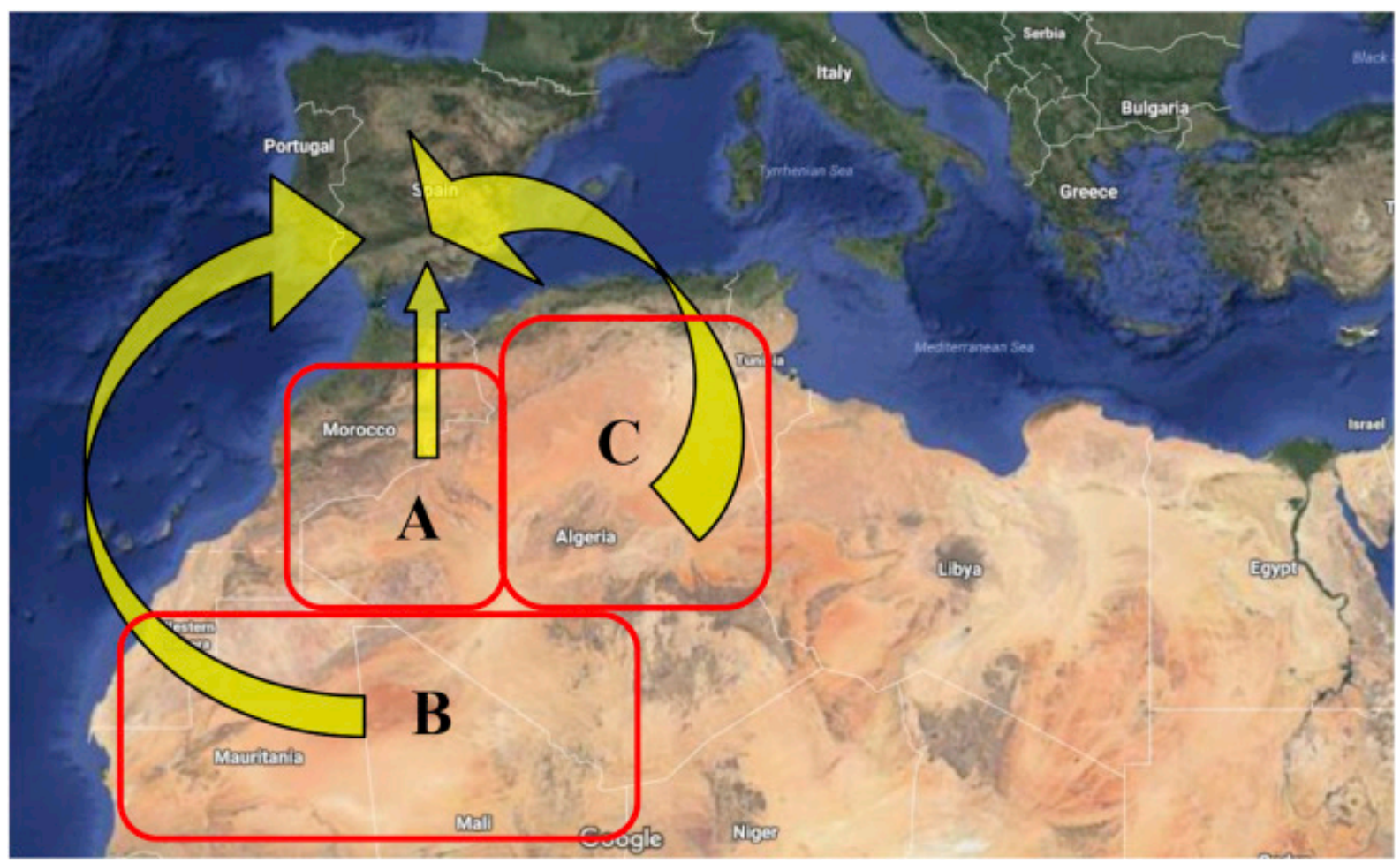

Fig. 1. Schematic presentation of the different scenarios of Saharan dust intrusions over Granada. Here are presented three potential Saharan dust sources A, B and C as well as three main pathways these events (from Google maps). 


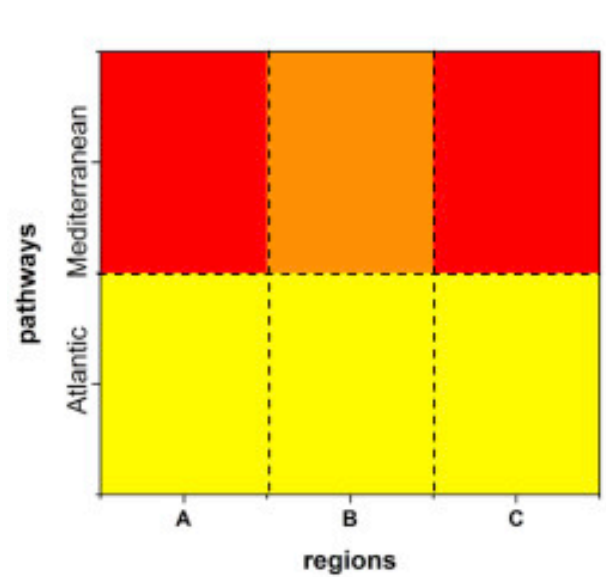

a)

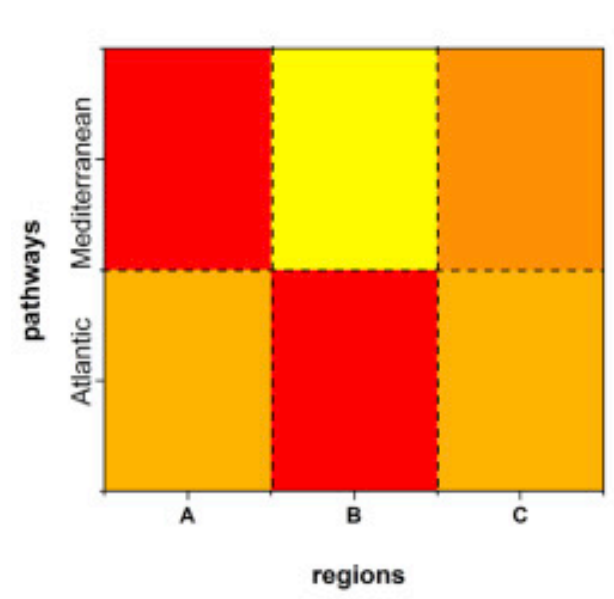

c)

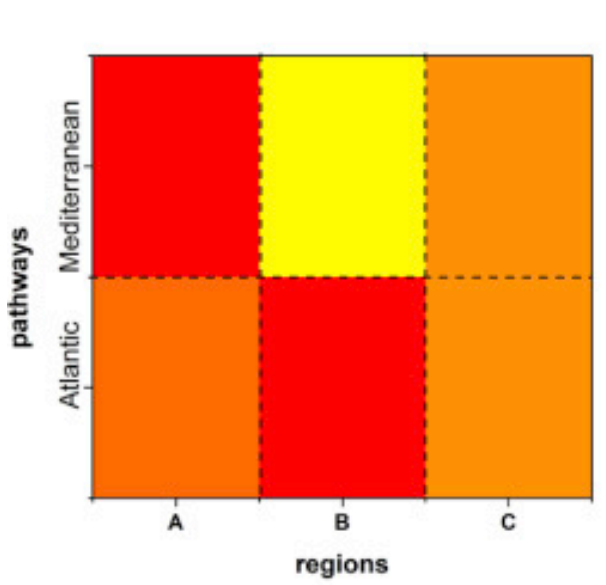

e)
$1000 \mathrm{~m}$ a.g.
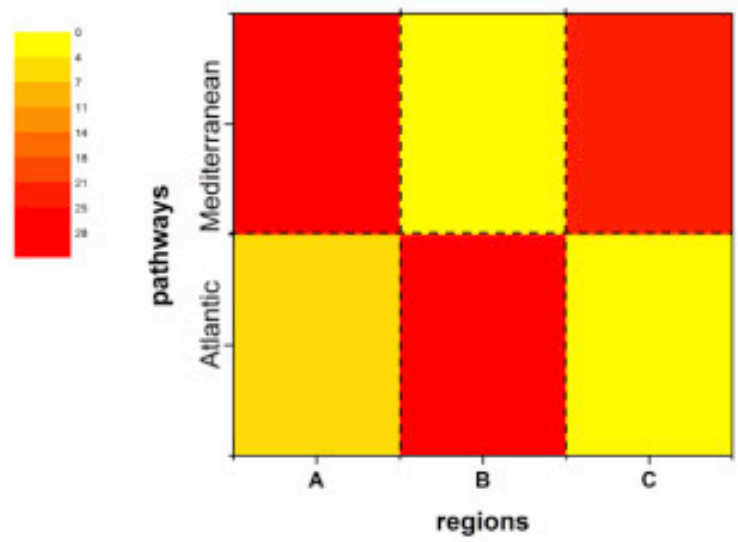

b)
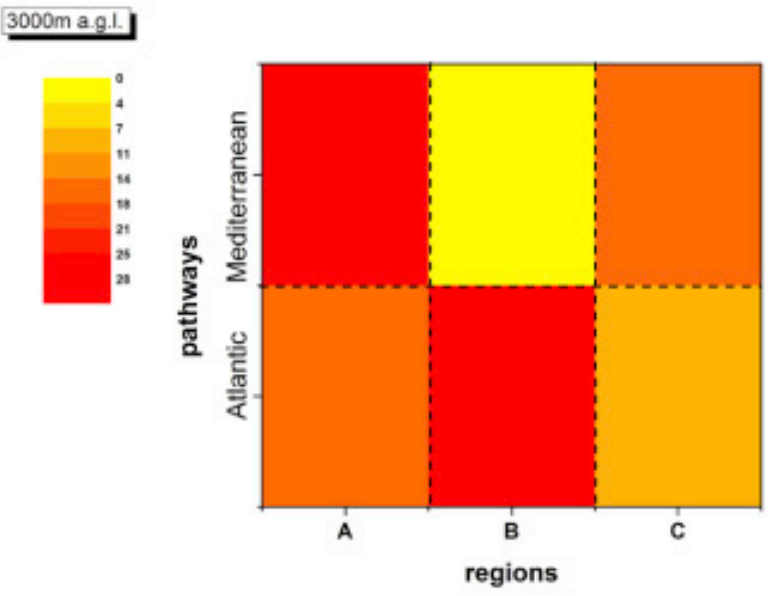

$4000 \mathrm{~m}$ a.g.

d)

$5000 \mathrm{~m}$ a.g.1.
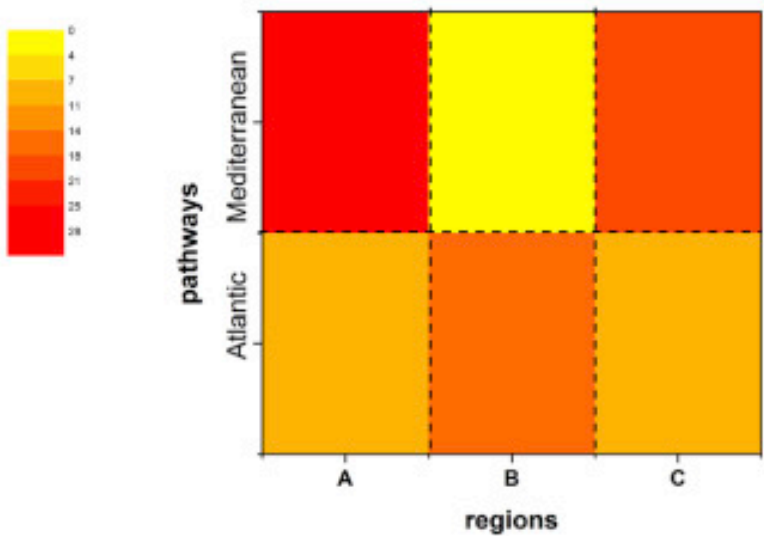

f)

Fig. 2. Contour plots of the frequencies of different scenarios of dust intrusions at each altitude. Color bars indicate the percentages (\%) of occurrence of each scenario. Highest percentages are presented by the red color, while lowest percentages are presented by the yellow color. These plots refer to six different altitudes; a) 1000 m, b) $2000 \mathrm{~m}$, c) 3000 m, d) 4000 m, e) $5000 \mathrm{~m}$ and f) $6000 \mathrm{~m}$. (For interpretation of the references to colour in this figure legend, the reader is referred to the web version of this article.) 
Klett-Fernald inversion algorithm (Fernald et al., 1972; Klett, 1981, 1985; Fernald, 1984) is applied to retrieve the height-resolved particle backscatter coefficients at 355, 532 and $1064 \mathrm{~nm}$, and derived properties such as the backscatter-related Angstrom exponent between $355 \mathrm{~nm}$ and $532 \mathrm{~nm}$. Based on lidar data, the top and bottom heights of dust layers were determined based on the derivative method of the particle backscatter coefficient at $532 \mathrm{~nm}$. After this, we have determined the geometrical thickness and the backscatter-weighted altitude of dust layers. Meanwhile, the backscatter-weighted altitude $\mathrm{Z}_{\mathrm{c}}$ at $532 \mathrm{~nm}$ are obtained by using the eq. (1) (Mona et al., 2006; Papayannis et al., 2009).

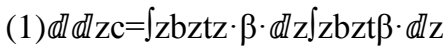

where, $\beta$ is the particle backscatter coefficient, $z$ is the altitude (a.g.l.) and $z_{c}$ is the height of the backscatter-weighted altitude.

4. Results

4.1. Classification of dust events observed over Granada

According to the methodology described in Section $\underline{3}$, data corresponding to the summer seasons (JulyAugust) of 2012 and 2013 was analyzed in detail. The number of the detected dusty days and dust events based on AERONET data for this period is included in Table 1. In the cases of non-availability of AERONET data, we have used the models NAAPS and BSC-DREAM as well as the MODIS products, to obtain AOD $_{550 n m}$ data.

Table 1. Number of dusty days observed over Granada in each month during the period July-August, 2012-2013 (AERONET data).

\begin{tabular}{|c|c|c|c|c|c|c|}
\hline & \multicolumn{3}{|c|}{ Number of dusty days } & \multicolumn{3}{|c|}{ Number of dust events } \\
\hline & July & & August & & & August \\
\hline 2012 & 14 & 21 & & 4 & 4 & \\
\hline 2013 & 7 & 16 & & 4 & 3 & \\
\hline Total & 21 & 37 & & 8 & 7 & \\
\hline
\end{tabular}

Based on the data of Table 1, there are identified in total 58 dusty days and 15 dust events in Granada during the period July-August, 2012-2013. During the period July-August 2012, 35 dusty days was observed, while in the same period of 2013 only 23 dusty days were observed. The major number of dust events was observed in August. In addition, AERONET data suggest that the dust events during August lasted more compared to July. The number of dusty days per dust event during the whole period was 3.6, with a standard deviation 2.4 .

Cluster analyses of HYSPLIT4 backward-trajectories from Sahara desert to Granada reveal three main source regions and two pathways. The combination of the source clusters and these pathways constitutes the scenarios of Saharan dust intrusions over Granada. 
For the analysed period, dust event occurrences (in \%) over Granada, according to the different scenarios of dust intrusion are as follows; region A (through Mediterranean) 35.5\%, region B (through Atlantic) 27.0\%, region C (through Mediterranean) 15.7\%, region A (through Atlantic) 11.4\%, region C (through Atlantic) 8.8\% and region B (through Mediterranean) 1.6\%. The most frequent scenario is the dust intrusion, originated in region A and passing through the Mediterranean. Very frequent are also dust intrusions from the region $\mathrm{B}$, which overpasses through the Atlantic. These results were also observed in previous studies (e.g. Goudie and Middleton, 2001). According to Valenzuela et al. (2012b), dust transport from region A is favoured by low pressure centered over Southeastern Portugal and a high pressure center over central Mediterranean. The anticyclone centered over North Africa, southeastern Iberian Peninsula and west of the Mediterranean, favors dust transport from region B. Meanwhile the low pressure centered over Morocco and high pressure centered over eastern Algeria and Tunisia, favor dust intrusions in Granada from region C. On the other hand, $98.4 \%$ of the air masses, which originate from region B pass through the Atlantic.

Furthermore, the analyses of these scenarios are realized at different altitudes; from $1000 \mathrm{~m}$ a.g.l. up to $6000 \mathrm{~m}$ a.g.l. Fig. 2 presents the frequency of occurrences of different scenarios of dust intrusions over Granada. The maximal altitude of dust intrusions during our analysis was $6000 \mathrm{~m}$. This value is in accordance with the maximal altitudes found by Guerrero-Rascado et al. (2009) and Tesche et al. (2009).

The plots in Fig. 2 show that the frequencies of different scenarios of dust intrusions over Granada are almost the same. The major difference was observed in the first plot, corresponding to $1000 \mathrm{~m}$ a.g.l. Nevertheless, this difference was not taken into consideration because of the low number of data (only 2.35\%) at this altitude. From the plots of Fig. 3, we see that the most frequent scenarios of dust intrusions over Granada are those which originate from region A and come through the Mediterranean as well as those from which originate region B and come through the Atlantic.

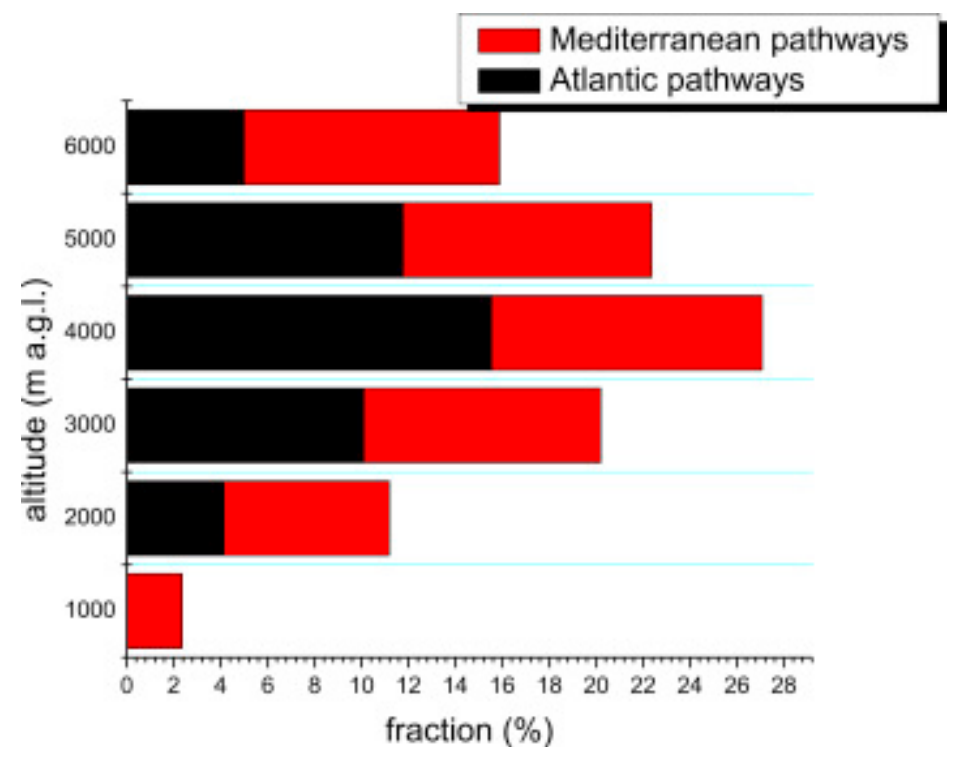


Fig. 3. The altitude distribution of the percentages of the total number of the 120-hr Hysplit backtrajectories at 12 UTC, with 3-hr resolution. This calculation was performed only during the dust events in Granada.

In short, we can state that all desert dust intrusions over Granada come through the Mediterranean (52.7\%) and Atlantic (47.3\%). On the other hand, both regions are responsible for a considerable fraction of dust intrusions over Granada. Their contributions are about 47\%, 29\%, and 24\%, respectively, from the regions A, B and C. Fig. 3 presents the distribution of the number of air masses coming in Granada from Saharan regions during the dust events according to the altitude of air mass arrivals.

$\underline{\text { Fig. } 3}$ presents the frequency distribution of backward-trajectories at several altitudes grouped according to their pathways from the Sahara Desert to Granada. According to Fig. 3 most of the air masses coming from the dust source regions overpass Granada at altitude range 3000-5000 m a.g.l. About 71\% of all air masses overpass Granada at this range of altitudes (igig. 3). This result is in accordance with previous studies, that found that the principal altitude range of Saharan dust intrusions was between 3 and $5 \mathrm{~km}$ (Papayannis et la. 2008; Mona et al., 2006). The plots in Fig. 3 indicate some important patterns of the altitude distribution of backward-trajectories at different pathways. Backward-trajectories at $1000 \mathrm{~m}$ come only through Mediterranean during the investigation period. This situation changes toward higher altitudes, where are obtained considerable numbers of backward-trajectories coming from both pathways. Backward-trajectories that arrive at $2000 \mathrm{~m}$ from the Atlantic count on about 37\% of all backwardtrajectories at this altitude. 40-50\% of all backward-trajectories at altitude 3000-5000 m over Granada came from the Atlantic. In the upper layers, $6000 \mathrm{~m}$ backward-trajectories are more likely to come through the Mediterranean (69\%).

\subsection{Columnar aerosol optical property's classification by dust cluster origins}

$\underline{\text { Table } 2}$ presents a statistical summary of daily and instantaneous values of $\mathrm{AOD}_{500}, \mathrm{AE}_{440-870}$, coarse mode contribution on AOD CM_AOD 500 and fine mode fraction FMF $_{500}$, for dust events observed at Granada on July and August 2012-2013 (derived from AERONET, level 2.0 when available, otherwise the level 1.5 was used).

Table 2. Principal statistical parameters of aerosol optical depth, Angstrom exponent, coarse mode contribution on AOD and the fine mode fraction during the whole period; July-August 2012-2013.

\begin{tabular}{|c|c|c|c|c|c|}
\hline & & \multicolumn{2}{|c|}{ Daily averaged data } & \multicolumn{2}{|c|}{ Instantaneous data } \\
\hline & & July & August & July & August \\
\hline \multirow[t]{4}{*}{ AOD $_{500}$} & Min. & 0.18 & 0.15 & 0.05 & 0.06 \\
\hline & Avg. & 0.30 & 0.35 & 0.25 & 0.31 \\
\hline & Max. & 0.42 & 0.98 & 0.61 & 1.13 \\
\hline & St.dev. & 0.08 & 0.16 & 0.12 & 0.16 \\
\hline $\mathrm{AE}_{440-870}$ & Min. & 0.32 & 0.13 & 0.17 & 0.02 \\
\hline
\end{tabular}




\begin{tabular}{|llllll} 
& & \multicolumn{2}{c}{ Daily averaged data } & \multicolumn{2}{r}{ Instantaneous data } \\
\cline { 3 - 6 } & \multicolumn{2}{c}{ July } & August & July & August \\
\cline { 2 - 6 } & Avg. & 0.56 & 0.50 & 0.71 & 0.58 \\
& Max. & 0.95 & 0.98 & 1.41 & 1.47 \\
& St.dev. & 0.21 & 0.24 & 0.30 & 0.30 \\
CM_AOD500 $_{50}$ & Min. & 0.13 & 0.09 & 0.03 & 0.03 \\
& Avg. & 0.22 & 0.26 & 0.17 & 0.22 \\
& Max. & 0.33 & 0.78 & 0.51 & 0.94 \\
& St.dev. & 0.07 & 0.14 & 0.10 & 0.14 \\
& Min. & 0.21 & 0.17 & 0.16 & 0.14 \\
& Avg. & 0.28 & 0.28 & 0.31 & 0.30 \\
& Max. & 0.48 & 0.59 & 0.56 & 0.80 \\
& St.dev. & 0.07 & 0.11 & 0.10 & 0.13
\end{tabular}

Intense dust events, with $\mathrm{AOD}_{500}$ higher than 0.30, were observed in 8 cases; 3 cases in July and 5 cases in August. The most intense dust intrusion was recorded on 2 August 2012. On this day, AOD $_{500}$ value (0.98) was the highest value of the analyzed period. This $\mathrm{AOD}_{500}$ value was 2.8 times higher than the whole August average. However, this value is lower than the maximal value (0.86-1.5) found by Guerrero-Rascado et al., 2009. Meanwhile, during this day we obtained also the lowest $\mathrm{AE}_{440-870}$ value (0.13) during all the dusty days, indicating a strong contribution of coarse dust particles on this day. The average value of coarse mode AOD $_{500}$ in August was 1.2 times higher than in July. On the other hand, a similar value of the average fine mode fraction ${ }_{500 \mathrm{~nm}}$ was obtained in July and August. These results demonstrate the stronger presence of dust on August.

Instantaneous data during the dusty days in Granada are used in Table 2. The average and median values (not shown here) are quite similar. This fact indicates that the averages are not influenced by the extreme values. Low average of instantaneous values of $\mathrm{AE}_{440-870}$ and $\mathrm{FMF}_{500}$, as well as high values of CM_AOD500 during all the days associated with dust event, confirms the presence of dust during these days.

The following results present the statistics on the instantaneous data of the aerosol optical properties.

The Fig. 4 presents the distribution of the values of instantaneous data $\mathrm{AOD}_{500}, \mathrm{AE}_{440-870}$, CM_AOD 500 and $\mathrm{FMF}_{500}$ during all the days associated with dust event. 


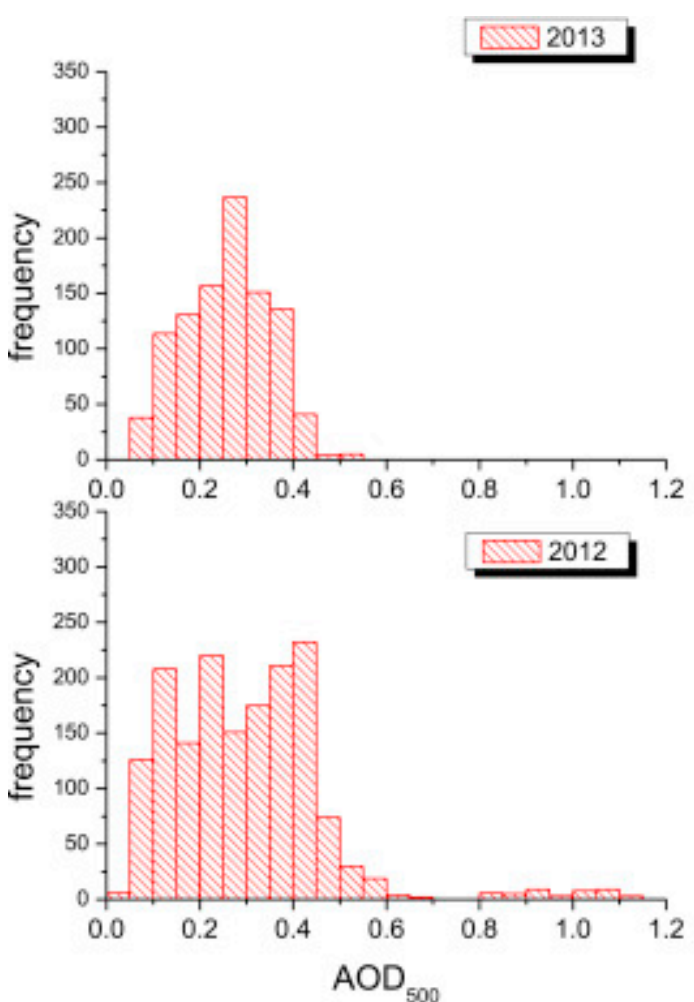

a)

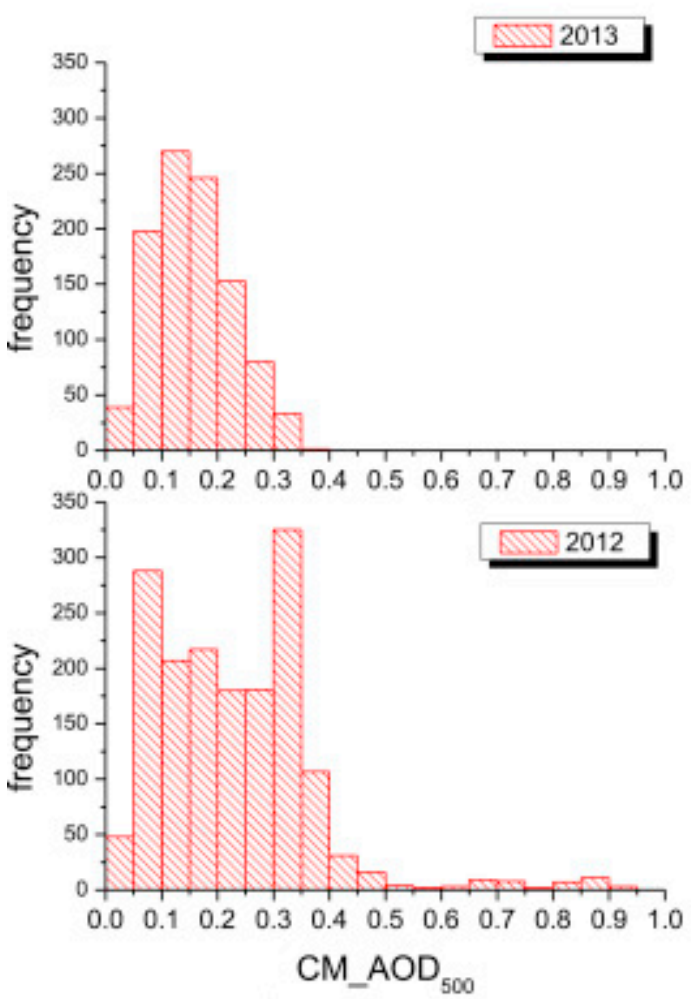

c)

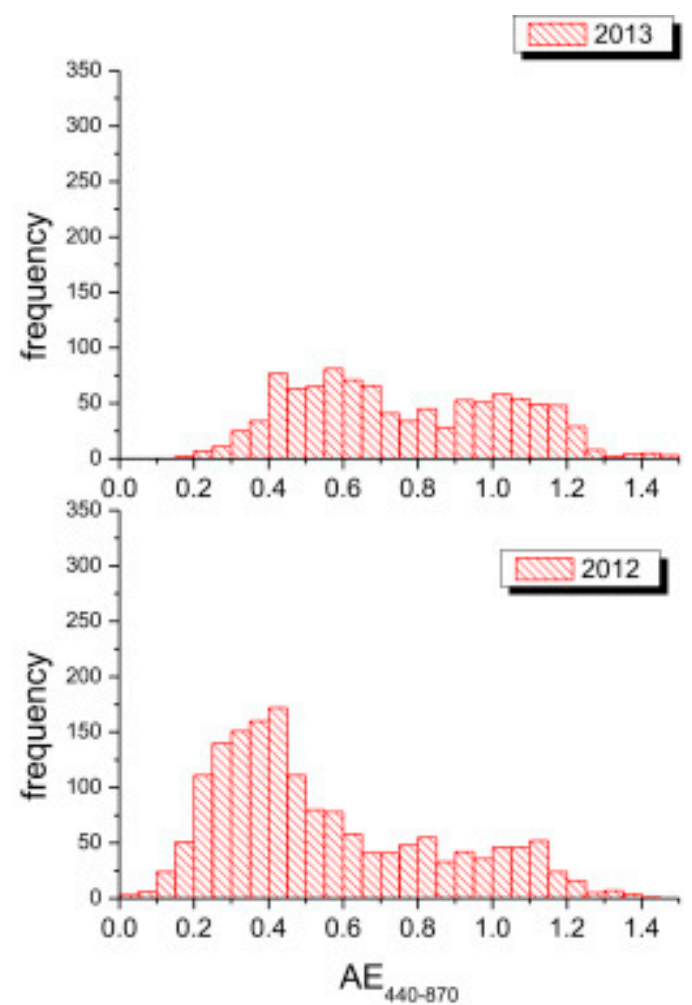

b)

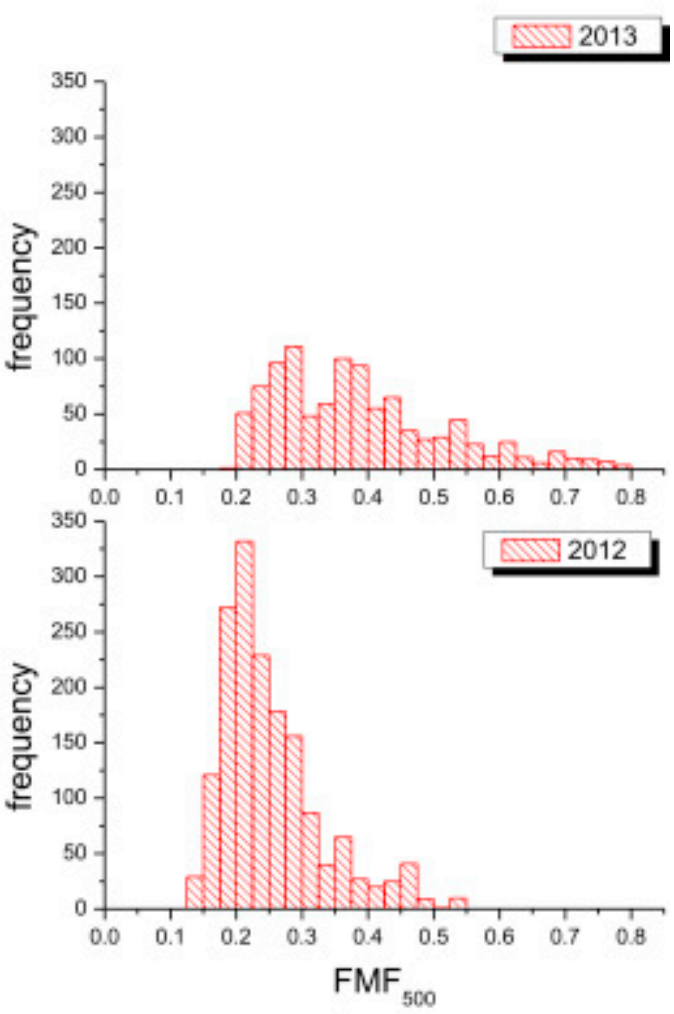

d)

Fig. 4. The frequencies in the plots present the number of the cases for aerosol data during dust events in Granada, analysed for two periods; July-August 2012 and 2013. The aerosol properties presented here are; a) $\mathrm{AOD}_{500}$, b) $\mathrm{AE}_{440-870}$, c) CM_AOD ${ }_{500}$ and d) $\mathrm{FMF}_{500}$. 
The upper limit of AOD 500 during 2012 was higher than in 2013, even though the frequencies of these values are relatively low. The distributions of $\mathrm{AE}_{440-870}$ present almost the same bimodal patterns during 2012 and 2013. Even this, the AE values tend to be lower during 2012. In addition, the pure dust conditions have been analyzed. These dust events are characterized by very low values of Angstrom exponent, $\mathrm{AE}_{440-870}<0.3$, (Kaufman et al., 2006; Tesche et al., 2009; Valenzuela et al., 2014). The percentage of data with $\mathrm{AE}_{440-870}<0.3$ were $20.4 \%$ in 2012 and only $2.1 \%$ in 2013 . The data of the CM_AOD 500 show a mono-modal distribution with the maximum of 0.05-0.35 for 2012 and 0.05-0.25 for 2013. Meanwhile, the distributions of the $\mathrm{FMF}_{500}$, have different patterns during two years. A clear maximum of $0.15-0.30$ was obtained in 2012. Smother distribution was obtained for 2013. A lower maximum, in this case, was reached at 0.25-0.40. Principal statistical parameters of AOD 500, AE $_{440-870 \text {, }}$ CM_AOD 500 and FMF500 $_{50}$ during the period July-August, 2012-2013, are presented in Table 3.

Table 3. Angstrom exponent at 355/532 nm $\left(\mathrm{AE}_{355 / 532}\right)$ and linear particle depolarization ratio at $532 \mathrm{~nm}$ (LPDR 532 ), using lidar measurements. These are averaged values according to dust origins and the pathways of air masses, during dust intrusions over Granada.

\begin{tabular}{clcccc} 
& \multicolumn{2}{c}{ AE $355 / 532$} & \multicolumn{2}{c}{ LPDR $_{532}$} \\
\cline { 2 - 5 } & \multicolumn{1}{c}{ Average } & St. dev. & Average & St. dev. \\
\hline Region A & 0.39 & 0.20 & 0.24 & 0.01 \\
Region B & 0.40 & 0.20 & 0.24 & 0.02 \\
Region C & 0.32 & 0.13 & 0.22 & 0.01 \\
Atlantic path & 0.41 & 0.22 & 0.22 & 0.02 \\
Mediterranean path & 0.38 & 0.17 & 0.21 & 0.01 \\
\hline
\end{tabular}

In order to better identify the AOD-AE frequency of occurrences during dusty days in Granada, a cluster analysis of columnar optical data is performed. This analysis was done implementing the K-Means algorithm (Aravind et al., 2010; Dall’Osto et al., 2012; Wong et al., 2013). K-means, which is a nonhierarchical clustering technique, starts with the random subdivision of objects into a number of clusters. The K-means algorithm starts with the initial assumption of the number of clusters K. Here, three clusters are chosen. These clusters belong to these three cases of AOD-AE pairs; high AOD and low AE, low AOD and high AE, and the intermediate case. Since $K=3$, we have 3 cluster centers, and they are initialized with random points. After the initial inputs, the procedure of the minimization of the distances of AOD-AE points to the centers of initial clusters gives the following results for cluster centers.

4.2.1. Cluster I (0.18:1.03), cluster II (0.39:0.33) and cluster III (0.23:0.60)

Data on the cluster I represent lowest AOD and highest AE values. This suggests a mixture of dust with fine mode aerosols. Cluster II represents dust cases characterized by highest AOD and lowest AE values. In this case, the coarse mode is dominant, which is a case similar to the pure dust events. Meanwhile, the remaining data of dust events in Granada are grouped in cluster III. This cluster contains intermediate data between the first two clusters. Both clusters contain an almost similar number of AOD-AE pairs. 
$28.7 \%$ of these data fall in the first cluster, $38.1 \%$ fall in the second and $33.2 \%$ fall in the third cluster. Fig. 5 presents the AOD-AE scatter-plots of AOD-AE values during all dust events in Granada.

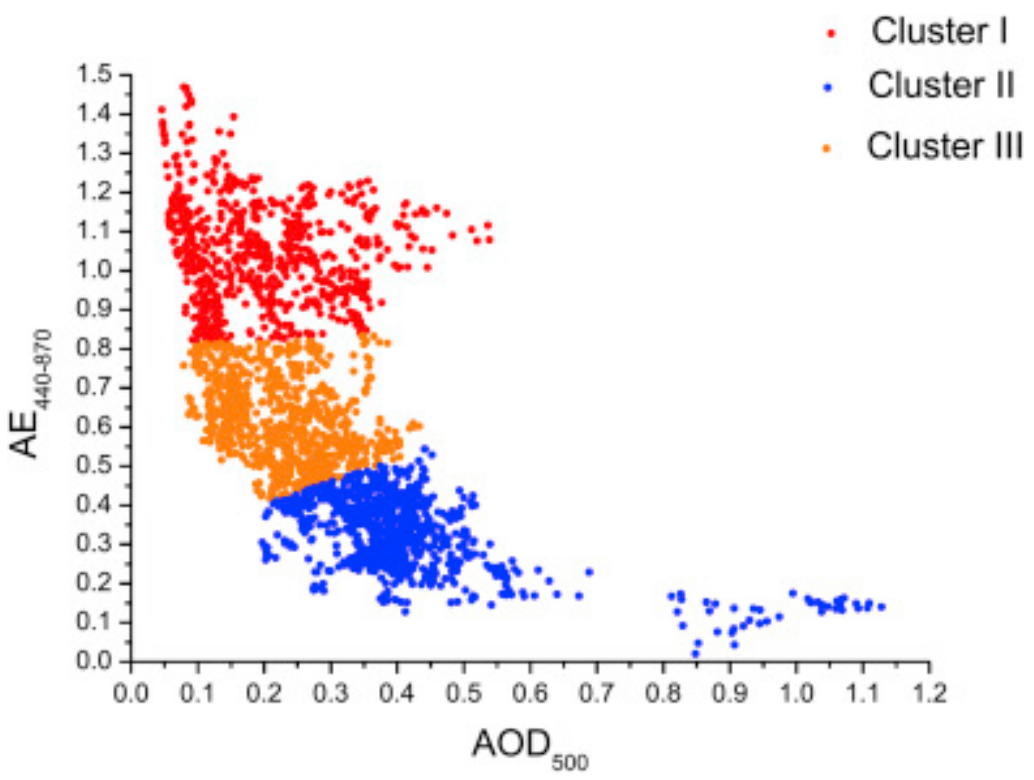

Fig. 5. Scatter-plot of AOD-AE instantaneous data during the periods July-August 2012 and 2013 in Granada. Here, cluster I represent the cases of lower aerosol load, mainly of fine mode, cluster II represents the cases of higher coarse mode aerosol load, whilst the data in the cluster III belong to the intermediate cases.

Data points shown are instantaneous retrievals during the July-August, 2012-2013. This is the reason that we can find in the Fig. 5 values, which exceed the thresholds for dust event determination. The scatterplot of the Fig. 5 presents all the data. However, the optimal cluster centers vary during different months. This variation is linked to the different mean values of AOD and AE during July and August, but this is not the scope of this work.

In order to investigate the aerosol optical properties, we have plotted averaged values of these properties during the scenarios of dust intrusions over Granada. Fig. 6 presents the averaged values plus the standard deviation of $\mathrm{AOD}_{500}, \mathrm{AE}_{440-870}, \mathrm{CM} \mathrm{AOD}_{500 \mathrm{~nm}}$ and the $\mathrm{FMF}_{500}$ according to cluster origins and the pathways of dust intrusions over Granada, during the dust events.
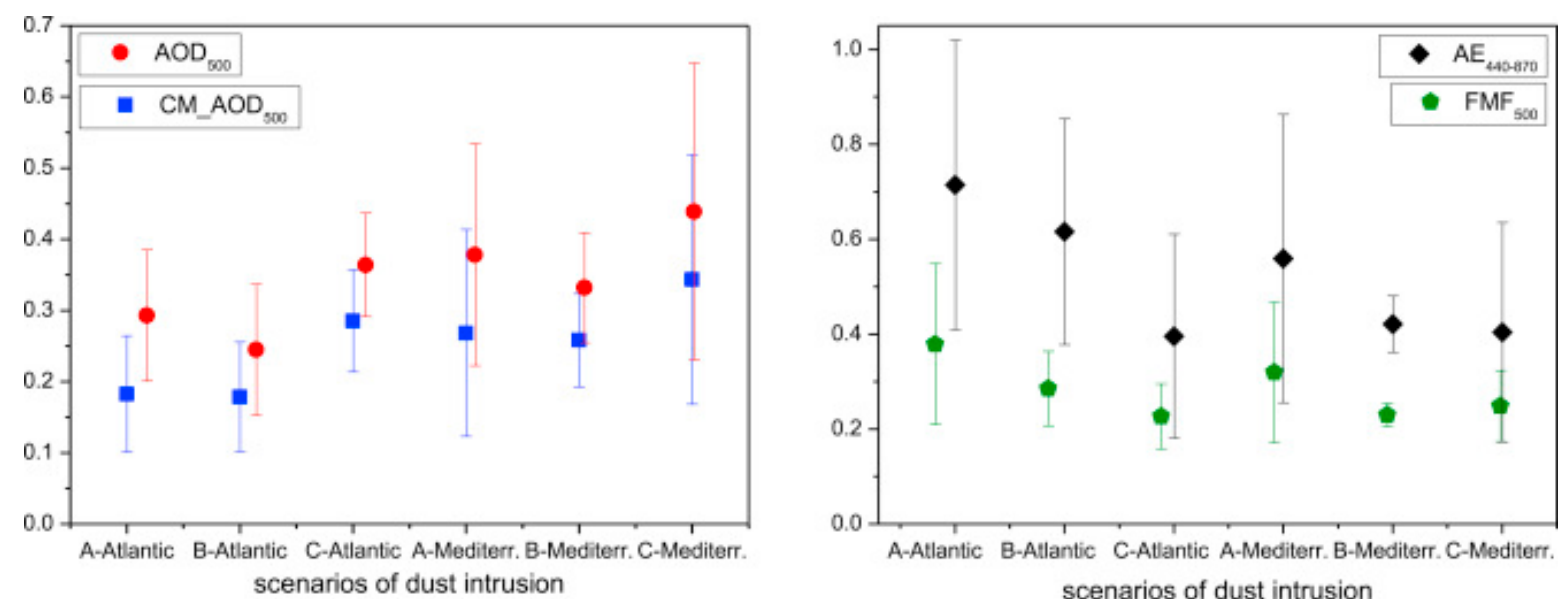
Fig. 6. Aerosol properties during different scenarios of dust intrusions in Granada. Mean values of $\mathrm{AOD}_{500}, \mathrm{AE}_{440-870}, \mathrm{CM} \mathrm{AOD}_{500}$ and $\mathrm{FMF}_{500}$ are plotted according to the six main scenarios of dust intrusion in Granada.

The dust intrusions that originate in region B and come over Granada through Atlantic have the lowest AOD values. Meanwhile, the dust intrusions, which originate from region $\mathrm{C}$ and those, which originate from region B and come through the Mediterranean, have generally the lowest fractions of the fine mode and the Angstrom exponent.

However, a direct relation between columnar aerosol optical properties measured by sun photometer and the origins and pathways of the air masses calculated by HYSPLIT4 backward-trajectories are difficult to obtain. This is because not all the backward-trajectories take part in the dust transport during certain dusty days. In this way, the column-integrated properties are related not only with the scenarios of the dust intrusions, but also with the number of backward-trajectories, which originate in those source regions.

The histograms of $\mathrm{AOD}_{500}, \mathrm{AE}_{440-870}, \mathrm{CM} \_\mathrm{AOD}_{500}$ and $\mathrm{FMF}_{500}$ according to the origins and the pathways of air masses, are presented in Fig. 7. 

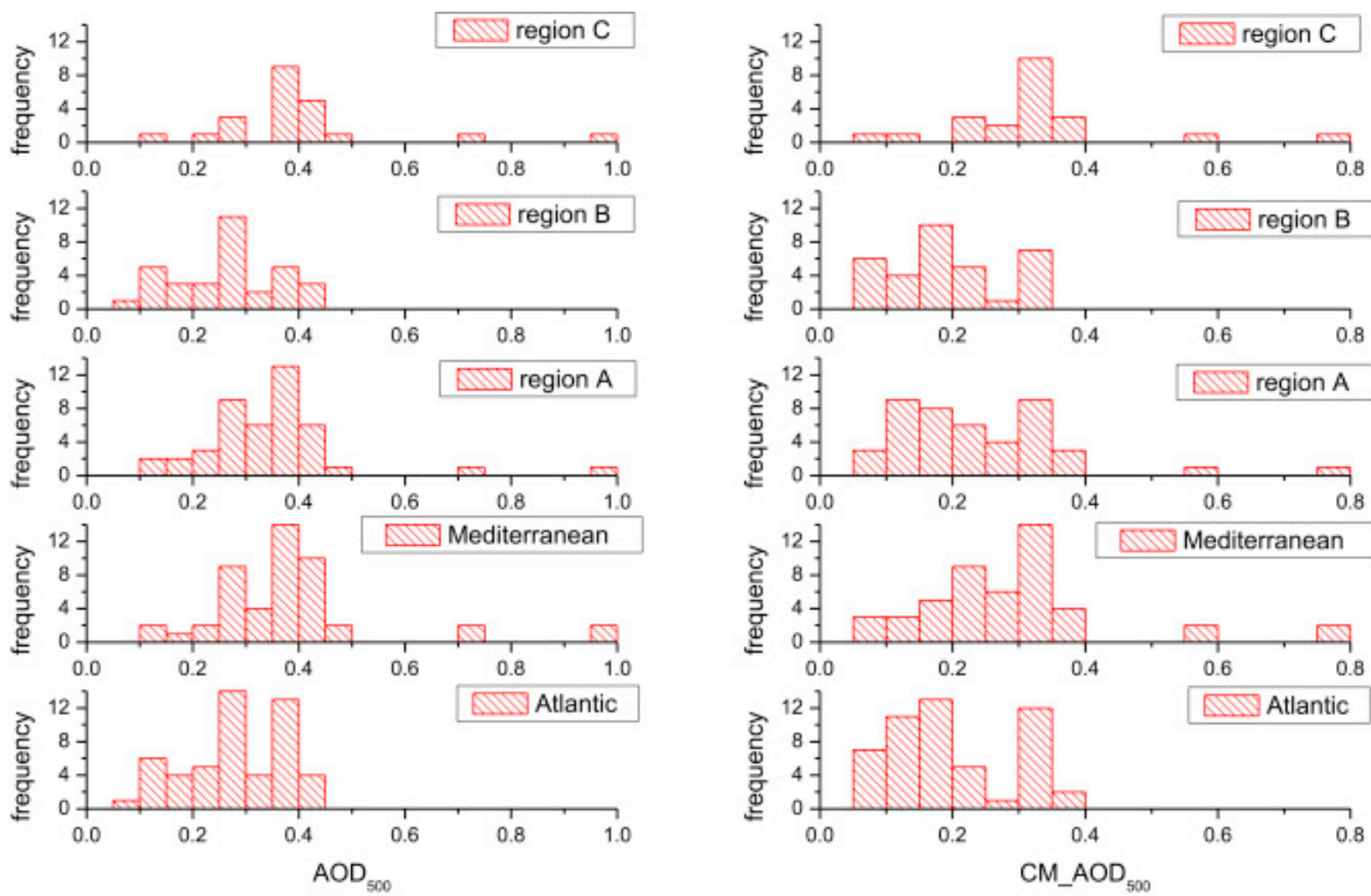

a)

b)
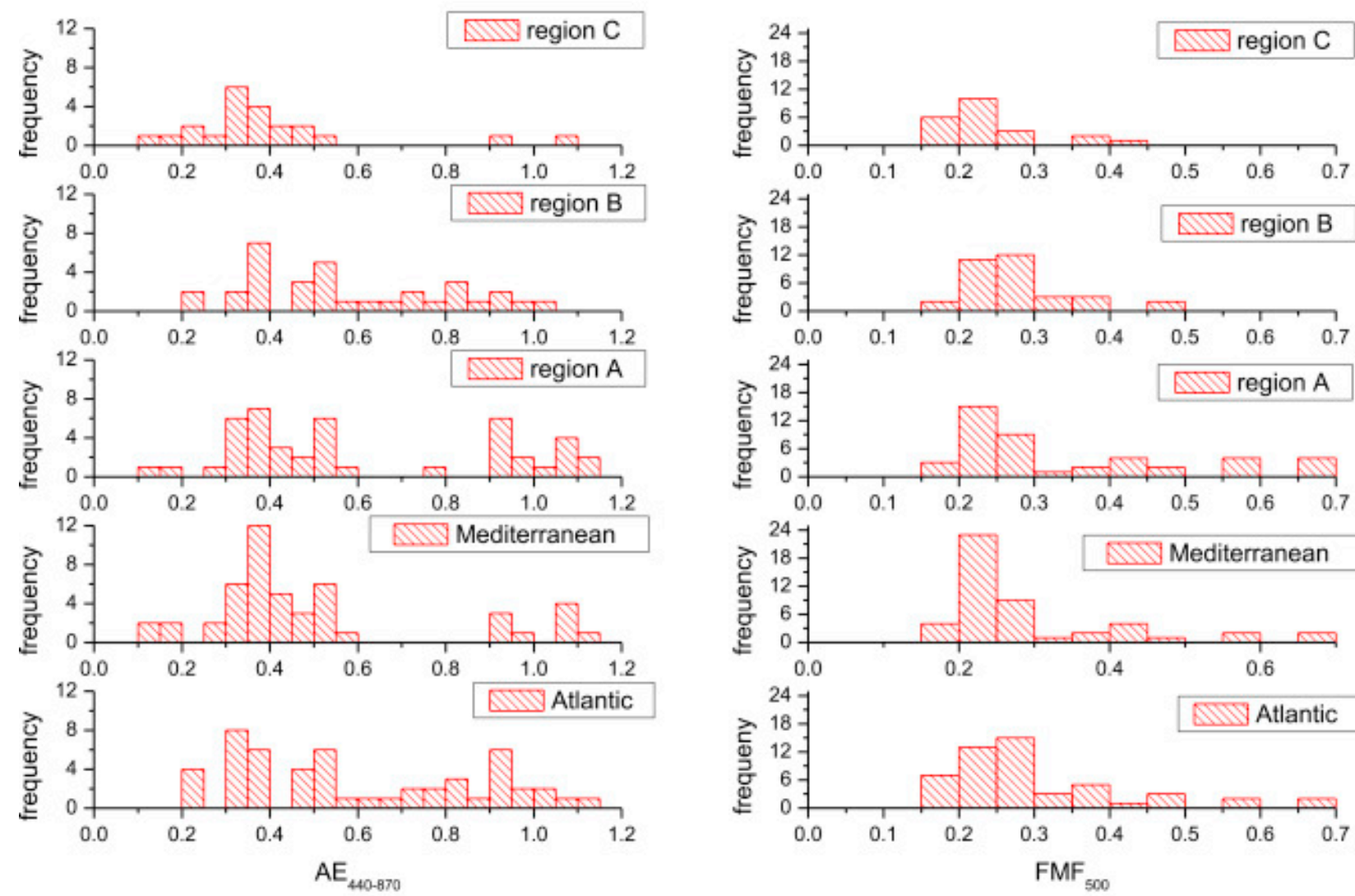

c)

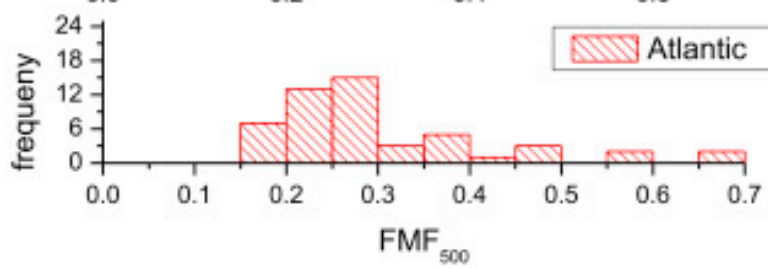

d) 
Fig. 7. Histograms of the distribution of several aerosol parameters during dust events over Granada. The number of cases (frequencies) for the daily averaged AERONET data in Granada during dust events; a) AOD 500 , b) CM_AOD 500, c) $\mathrm{AE}_{440-870}$ and d) $\mathrm{FMF}_{500}$.

Aerosol optical depth in Granada, under dust intrusions through the Mediterranean pathways, is 1.3 times higher than dust intrusions through Atlantic pathway. The mean values of AOD for the pathway from the Atlantic and Mediterranean are $0.28 \pm 0.10$ and $0.39 \pm 0.17$ respectively. Lower AOD values in the cases of dust intrusion through Atlantic may be attributed to the larger backward-trajectories through the Atlantic pathway. During the larger trajectories through the Atlantic, deposition process (especially of the coarse mode particles) contributes to the decrease of AOD. In addition, the pathways over Mediterranean may be affected by possible additional aerosol sources in this region. On the other hand, the values of the $\mathrm{AE}$ are higher during the transport through Atlantic compared to the Mediterranean. Their respective AE values are; $0.57 \pm 0.25$ and $0.43 \pm 0.20$. This result supports the hypothesis of coarse mode reduction during the Atlantic pathway compared to the other pathways. Anyway, these differences are not significant, when one takes into consideration also their uncertainness. Lower contribution of coarse mode on AOD and consequently higher fine mode fraction was obtained during the dust intrusions through Atlantic compared to the Mediterranean pathway. However, the mean values of these parameters don't differ too much. The mean value of the coarse mode AOD $_{500}$ was $0.20 \pm 0.09$ for the Atlantic transport and $0.29 \pm 0.15$ for the Mediterranean case. The differences in $\mathrm{AOD}_{500}$ and CM_AOD 500 according to the two pathways were almost the same. This fact suggests that the differences on $\mathrm{AOD}_{500}$ seem to be associated with the coarse contribution. Meanwhile, the mean value for the $\mathrm{FMF}_{500}$ was $0.30 \pm 0.12$ and $0.29 \pm 0.13$ for the transport through the Atlantic and the Mediterranean respectively. Even that the mean values of the fine mode fraction are almost the same, their statistical distribution (Fig. 7) indicates that their modes are different; 0.30 for the Atlantic and 0.25 for the Mediterranean pathways.

The analyses according to the origins of air masses confirm that air masses originating from region $\mathrm{B}$ have lower $\mathrm{AOD}_{500}$. Region $\mathrm{B}$ is more distant from Granada compared to the other regions and the principal pathways originating from this cluster pass through the Atlantic. These facts could explain the lower $\mathrm{AOD}_{500}$ during the dust events in Granada originating from the region B.

Information about dust emission rate and surface concentrations provided by the DREAM model indicate some differences between the three regions. Mean emission rates at regions A and C were 2.02 and $1.90 \mu \mathrm{gm}^{-2} \mathrm{~s}^{-1}$ respectively. These values are significantly lower than the emission rate forecasted for the region $\mathrm{B}$, which has a mean value of $2.58 \mu \mathrm{gm}^{-2} \mathrm{~s}^{-1}$. The mean values of surface dust concentrations are

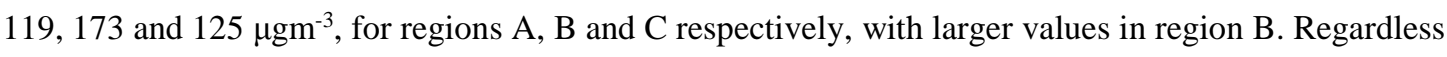
the largest dust emission rate found in region B dust intrusions with this origin result in lower $\mathrm{AOD}_{500}$ over Granada. Thus, the transport process affected more the aerosol load over Granada than the dust emission over the origin region. 
The mean values of $\mathrm{AOD}_{500}$ are $0.35 \pm 0.14,0.26 \pm 0.09$ and $0.41 \pm 0.17$ for regions $\mathrm{A}, \mathrm{B}$ and $\mathrm{C}$ respectively, with the lowest values associate to region $B$. The average values of the $\mathrm{AE}_{440-870}$ for air masses with these origins are $0.52 \pm 0.25,0.57 \pm 0.22$ and $0.37 \pm 0.16$. The aerosol optical properties of air masses originating from regions $\mathrm{A}$ and $\mathrm{B}$ are almost the same. Lower values of $\mathrm{AE}_{440-870}$ in the cases of air masses, which originate from region $\mathrm{C}$ may be related to the fact that the air masses which originate in region C usually overpass both regions $\mathrm{A}$ and $\mathrm{C}$ in their path to the Iberian Peninsula. The above statement is supported by the backward-trajectories, especially those at the lowest altitudes. This process increments the dust intake and its transport from these regions to Granada. Mean CM_AOD Doo $_{5}$ for regions $\mathrm{A}, \mathrm{B}$ and $\mathrm{C}$ are $0.24 \pm 0.13,0.19 \pm 0.08$ and $0.32 \pm 0.14$ respectively. Meanwhile, mean $\mathrm{FMF}_{500}$ are $0.34 \pm 0.16,0.28 \pm 0.07$ and $0.24 \pm 0.07$. Air masses, which come from region $\mathrm{C}$, have the highest $\mathrm{CM}_{-} \mathrm{AOD}_{500}$ and the lowest $\mathrm{FMF}_{500}$. CM_AOD $\mathrm{AO}_{500}$ was higher in the region $\mathrm{A}$ than region $\mathrm{B}$, despite the higher fraction of the fine mode for the region A compared to the region $\mathrm{B}$. This higher fraction of the fine mode is related to the higher anthropogenic activities, which generally carry out in the North-West African region (Rodriguez et al., 2011; Valenzuela et al., 2012b; Cowie et al., 2014).

In short, the air masses, which come through the Mediterranean, have higher $\mathrm{AOD}_{500}$ and $\mathrm{CM}_{-} \mathrm{AOD}_{500}$, lower $\mathrm{AE}_{440-870}$ and $\mathrm{FMF}_{500}$, compared to the air masses, which come through the Atlantic. Air masses, which originate in region $\mathrm{C}$, have the highest $\mathrm{AOD}_{500}$ and $\mathrm{CM}_{-} \mathrm{AOD}_{500}$, and the lowest $\mathrm{AE}_{440-870}$ and $\mathrm{FMF}_{500}$. Meanwhile, the air masses, which originate in region B, have the lowest $\mathrm{AOD}_{500}$ and $\mathrm{CM}_{-}$ $\mathrm{AOD}_{500}$, and the highest $\mathrm{AE}_{440-870}$ and $\mathrm{FMF}_{500}$.

The most frequent scenarios of dust intrusions over Granada are those originating in region A and over passing Mediterranean (35.5\%) and those, which originate in region B and come through Atlantic (27.0\%). Based on the above discussions, the first scenario is characterized by air masses with higher AOD and coarse mode contribution on AOD as well as a lower Angstrom exponent and fine mode fraction. Meanwhile, the opposite values were observed during the second scenario.

\subsection{Lidar profiles during dust events}

In these analyses, the altitude profiles of particle backscatter coefficients 355, 532 and $1064 \mathrm{~nm}$ during dust events in Granada are computed. The vertical profiles of the linear particle depolarization ratio $\mathrm{LPDR}_{532}$ and backscatter-related Angstrom exponent $\mathrm{AE}_{355 / 532}$ are computed too. The particle backscatter profiles are used to determine the geometrical properties of dust layers, while the $\mathrm{AE}_{355 / 532}$ and $\mathrm{LPDR}_{532}$ profiles are used to investigate the size and the shape, respectively, of the aerosol particles inside these dust layers. Averaged values of $\mathrm{AE}_{355 / 532}$ and $\mathrm{LPDR}_{532}$ calculated for the decoupled dust layers were 0.60 and 0.23 respectively. These values indicate a presence of coarse and non-spherical aerosols, which are the main characteristic of desert dust aerosol.

The geometrical properties of dust layers are key variables that characterize dust intrusions. Principal geometrical variables studied here, are the base and top height of the dust layers, their thickness and the backscatter-weighted altitude. All these parameters are determined during dust events over Granada in the 
period July and August 2012-2013. The box charts in Fig. 8 presents the values of average, standard deviation, median, $25 \%$ and $75 \%$ percentiles, as well as the values of base and top height of the dust layers, their thickness and the backscatter-weighted altitude of dust layers under dust events during all the investigation period in Granada.

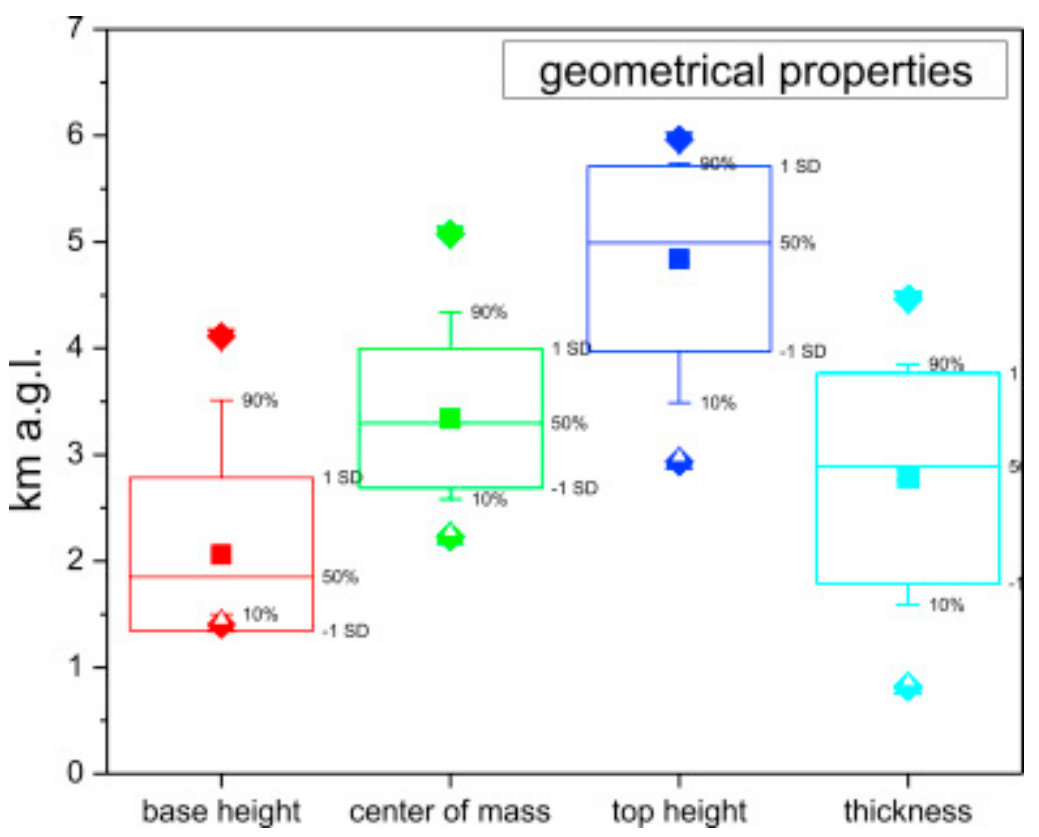

Fig. 8. Principal geometrical parameters of dust layers over Granada during July-August, 2012-2013.

Mean base (red box), center of mass (green box), top height (blue box) and the thickness (light blue box). The boxes include the median and are extended up to 1 standard deviation. The whiskers present 10-90\% of the values. The min-max values are also indicated on these plots. (For interpretation of the references to colour in this figure legend, the reader is referred to the web version of this article.)

The average base and top height of all dust layers during the investigation period were $2.1 \pm 0.7$ and $4.8 \pm 0.9 \mathrm{~km}$. Meanwhile, the average backscatter-weighted altitude was obtained at $3.3 \pm 0.7 \mathrm{~km}$, and the mean layer thickness was $2.8 \pm 1.0 \mathrm{~km}$. At the altitude range $2-5 \mathrm{~km}$, obtained by lidar measurements, are found $81.77 \%$ of all backward-trajectories passing over Granada during dust events. Thus, both lidar measurements and HYSPLIT4 model support the result about the altitude range of dust layers over Granada during the analyzed period.

Some differences between geometrical properties of dust layers during July and August were obtained. The average value of the base height of dust layers in July results higher than in August, differing by about $0.4 \mathrm{~km}$. Meanwhile, the average top height in August is $0.1 \mathrm{~km}$ higher than in July. This provides that dust layers in August are thicker than in July, by an average value of $0.5 \mathrm{~km}$. An important variable is also the backscatter-weighted altitude of the dust layers. The backscatter-weighted altitude of dust layers in July is $310 \mathrm{~m}$ higher than in August. The differences between the base heights and the backscatterweighted altitude may be related to the different pattern of altitude profiles of the dust layers during these two months. The dust layers with their base height higher than the planetary boundary layer height (PBL), are considered as decoupled dust layers. We have identified decoupled dust layers in $80 \%$ of the analyzed 
cases during July (the cases with available lidar data). This percentile was much lower during August. Only $42.9 \%$ of the analyzed cases are classified as decoupled dust layers in August, while the other $57.1 \%$ are classified as mixed with PBL.

Several studies have estimated the characteristics of the aerosol dust layers (Mona et al., 2006;

Papayannis et al., 2008, 2009). The overall results over the European continent show that the mean thickness of the dust layer typically stayed around 1.5-3.4 km and the corresponding mean backscatterweighted altitude ranged from 3.0 to $3.8 \mathrm{~km}$. Meanwhile, their mean base and top heights ranged on the intervals 1.4-4.7 km and 3.6-7.2 km. The mean values of base and top heights as well as the backscatterweighted altitude and thickness, obtained in the case of Granada, fall inside the above-mentioned intervals found over the continent. This fact provides an accordance of this study with the previous for Saharan dust layers over the European continent.

In total, during this period 231 lidar profiles were computed; 145 in August and 86 in July. Fig. 9 presents the averaged profiles of $532 \mathrm{~nm}$ backscatter coefficient, $532 \mathrm{~nm}$ linear particle depolarization ratio, and 532/355 nm backscatter-related Angstrom exponent for the whole investigation period; July-August, 2012-2013.
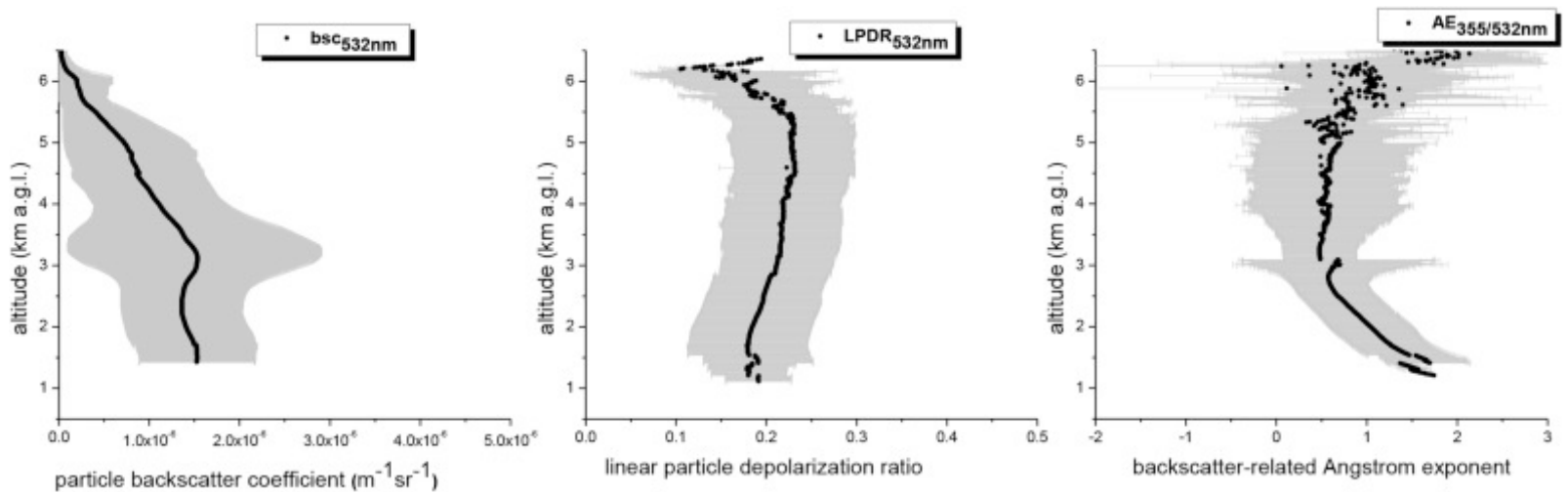

Fig. 9. Averaged altitude profiles of the backscatter coefficient at $532 \mathrm{~nm}$, linear particle depolarization ratio at $532 \mathrm{~nm}$ and Angstrom exponent at 355/532 nm during dust events in Granada (gray indicates standard deviation).

The average profile of bsc532, shows a maximum in the altitude range $2.3-5.0 \mathrm{~km}$. Below $2 \mathrm{~km}$, $\mathrm{AE}_{355 / 532}$ is higher than 1.0 and $\mathrm{LPDR}_{532}$ is lower than 0.19 . However, the mean values of these properties inside the layer (above $2.3 \mathrm{~km}$ ) are 0.58 and 0.22 respectively. The value of bsc $_{532}$ in the center of the layer and at its bottom is 1.54 and $1.36 \mathrm{~m}^{-1} \mathrm{sr}^{-1}$. The geometrical pattern of the average profiles of bsc $_{532}$ and the above values of the AE and LPDR shows a decoupled layer with its maximum at $3.1 \mathrm{~km}$ decreasing continuously with the altitude. The mean values of $\mathrm{AE}_{355 / 532}$ and $\mathrm{LPDR}_{532}$ strongly confirm the presence of large and irregular shaped particles (Sassen, 2005; Ansmann et al., 2012; Burton et al., 2012). These results indicate the presence of dust layers at these altitudes during the investigated period in Granada. 
The further step of these analyses is the identification of the differences of aerosol optical properties of dust intrusions from different clusters and pathways. For this purpose, there are estimated the mean values of $\mathrm{AE}_{355 / 532}$ and $\mathrm{LPDR}_{532}$ inside of the dust layers obtained by averaging lidar profiles of bsc532 according to the three clusters and two pathways. Fig. 10presents the profiles of bsc532 during dust intrusions in Granada, according to their origins and pathways.
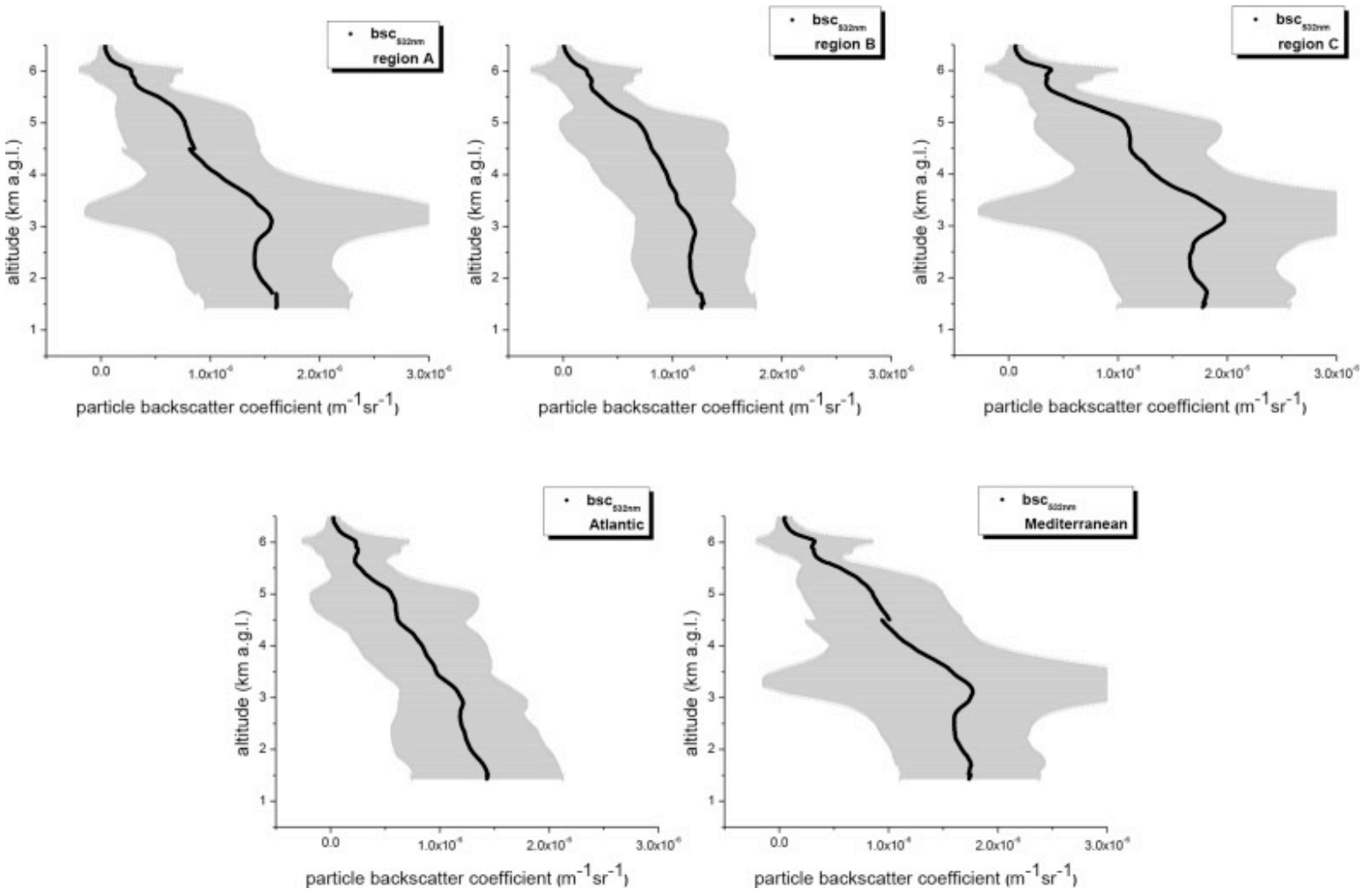

Fig. 10. Particle backscatter coefficient profiles during dust intrusion over Granada (gray indicates standard deviation). Averaged bsc $_{532}$ of dust intrusions according to the main regions (A, B and C) and pathways (Atlantic and Mediterranean) are presented.

Higher values of bsc $_{532}$ are obtained during the dust events over Granada, which originated from regions A and C. These regions are the closest to the Iberian Peninsula. According to the previous discussions, one of the most frequent scenarios of dust intrusion over Granada is that, which originate in region B and come through the Atlantic. However, the plots of Fig. 11 indicate that these dust intrusions are less intense compared to the others. During the scenarios of dust intrusions, different patterns of backscatter coefficient profiles were obtained. The average bsc532 profiles of dust intrusions, which originate from regions $\mathrm{A}$ and $\mathrm{C}$ as well as those, which come through the Mediterranean, show the maximum above PBL, which indicate the presence of decoupled layer. Meanwhile, those dust intrusions with origin at region $\mathrm{B}$ and Atlantic pathway, are mixed with PBL. This evidence may be related to the fact that the dust plume has to overpass the altitude of the Atlas chain during the dust intrusions through the Mediterranean. The presence of these mountains complicates the passage of air masses at lower altitudes, enabling the creation of decoupled layers during these dust intrusions. 

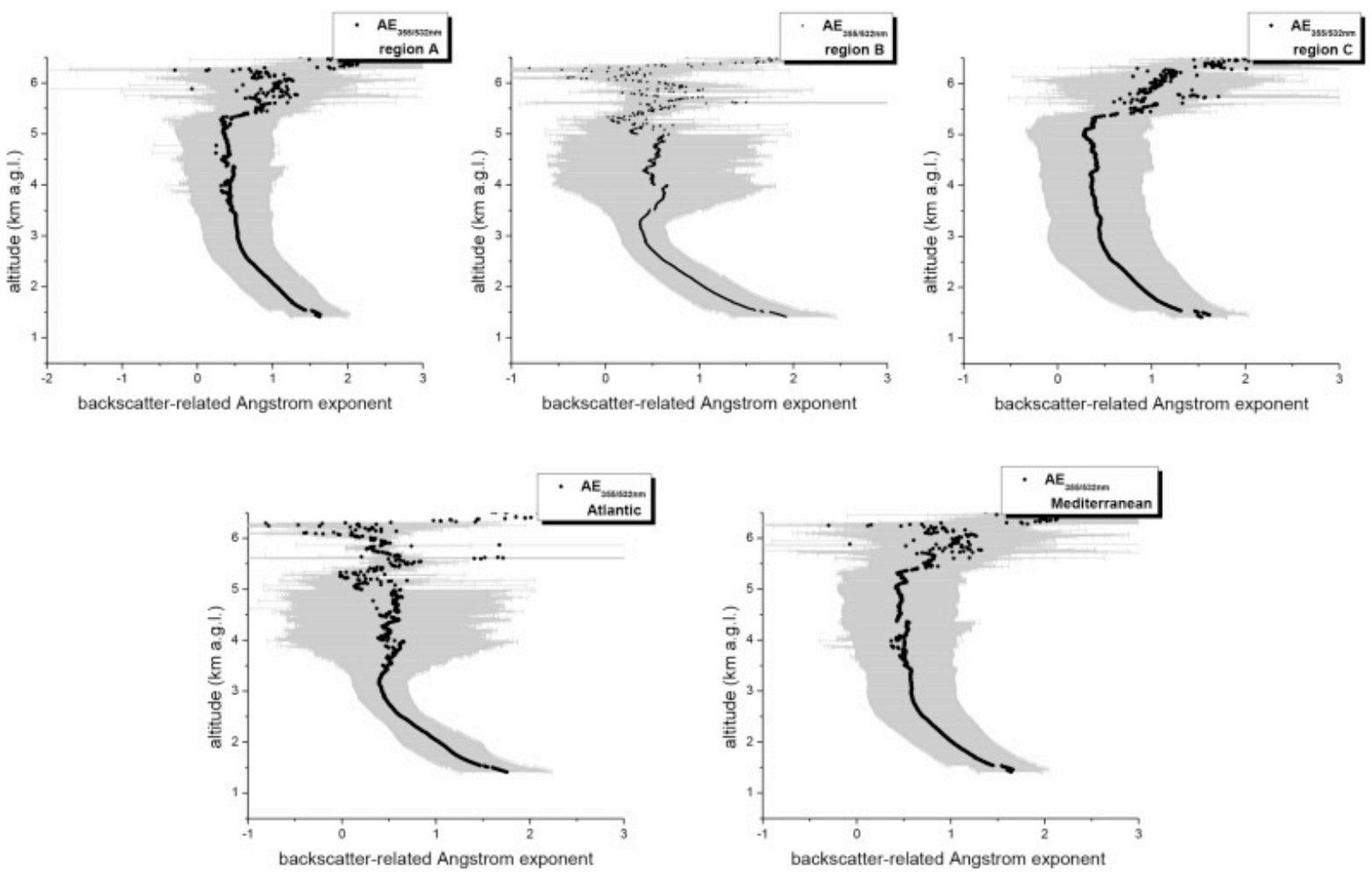

Fig. 11. Backscatter-related Angstrom exponent at 355/532 nm during dust intrusion scenarios over Granada (gray indicates standard deviation). Averaged $\mathrm{AE}_{355 / 532}$ of dust intrusions according to the main regions (A, B and C) and pathways (Atlantic and Mediterranean) are presented.

Altitude profiles of backscatter-related Angstrom exponent and Linear Particle Depolarization Ratio according to the dust intrusion scenarios are displayed in Figs. 11 and 12.
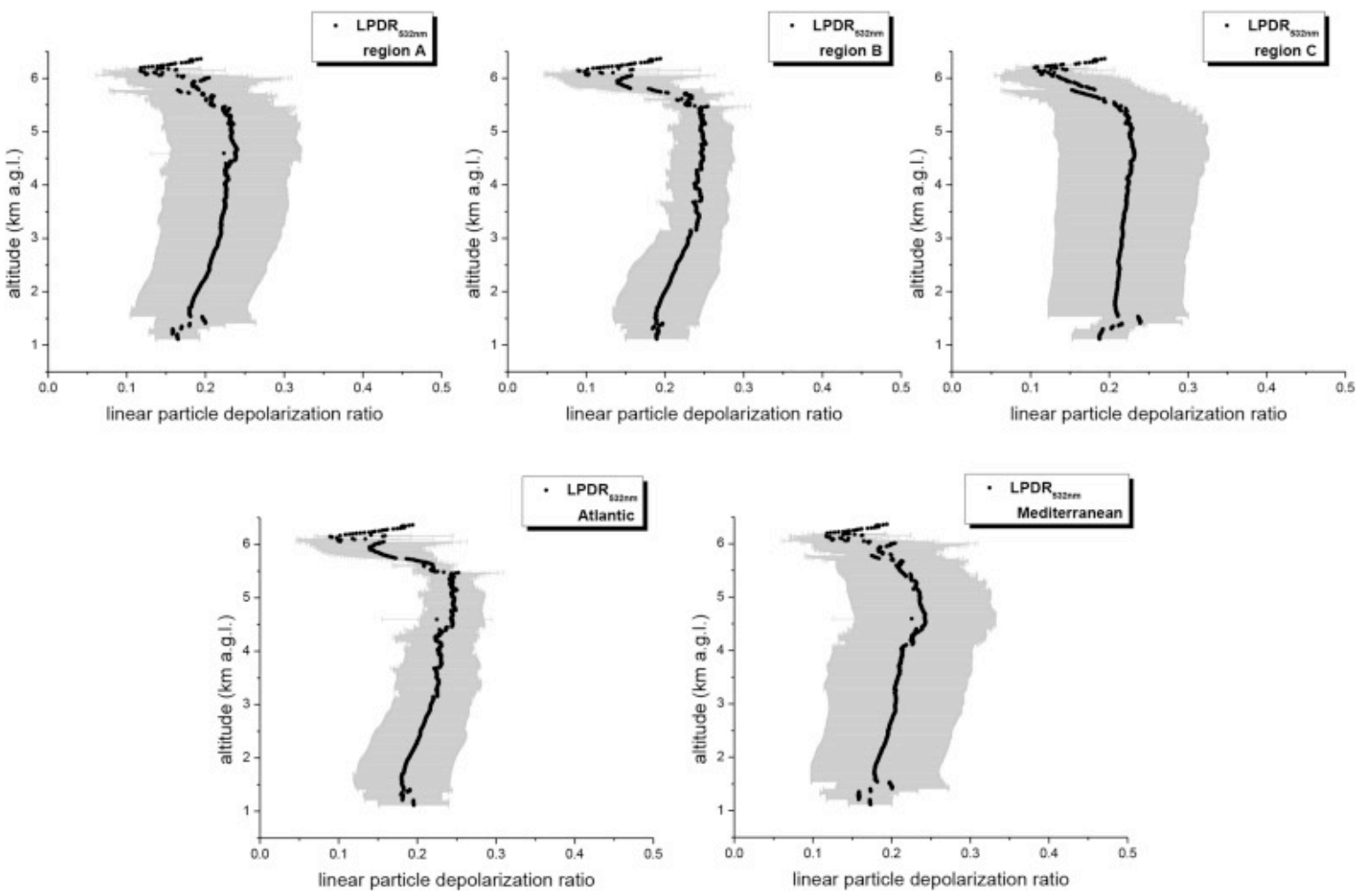
Fig. 12. Linear Particle Depolarization Ratio at $532 \mathrm{~nm}$ profiles during dust intrusion scenarios over Granada (gray indicates standard deviation). Averaged LPDR 532 during dust intrusion scenarios over Granada, according to the main regions (A, B and C) and pathways (Atlantic and Mediterranean) are presented.

The $\mathrm{AE}_{355 / 532}$ profiles for the dust intrusions, which originate at regions $\mathrm{A}$ and $\mathrm{C}$, and come through the Mediterranean, show very similar patterns. These patterns differ from those of dust intrusions, which originate in region B and come through the Atlantic. This fact is in accordance with the similarities between profiles of bsc $_{532}$. On the other hand, all the profiles of LPDR $_{532}$ are similar to each other. The only exception comes from the case of region $\mathrm{C}$, which has a different pattern of the LPDR 532 profile.

Average values of the $\mathrm{AE}_{355 / 532}$ and $\mathrm{LPDR}_{532}$ inside the dust layers give more insight on the differences aerosol optical properties among the different dust intrusions over Granada. Table 3 presents their average values and their standard deviation during different scenarios of dust intrusions in Granada.

Values of $\mathrm{AE}_{355 / 532}$ and $\mathrm{LPDR}_{532}$ in $\underline{\text { Table } 3}$ are calculated taking into account the lidar profiles of the dust plume. This was based on the previous discussions about the geometrical properties of dust layers. These results indicate similar average values of $\mathrm{AE}_{355 / 532}$ for the regions $\mathrm{A}$ and the region $\mathrm{B}$, and lower value in the case of the region C. This result is supported by the same results in the case of column integrated Angstrom exponent at 440-870 nm. However, the average values of backscatter-related Angstrom exponent were almost similar in the case of Mediterranean pathway compared to Atlantic pathway. The same result was obtained using the AERONET data. Values of Angstrom exponent obtained from lidar measurements were lower than the values provided by AERONET for all dust intrusion scenarios. The reason for these differences was because the lidar AE values are averaged only inside the dust layers, while the column-integrated AERONET data take into account the whole column. Despite their differences, the correlation coefficient between lidar and column-integrated values of the Angstrom exponent for all cluster and pathway scenarios was relatively high, 0.91 . On the other hand, the average values of LPDR $_{532}$ were almost equal for all scenarios of dust intrusion. In short, the principal difference comes from the dust intrusions, which originate in region $\mathrm{C}$. The dust events, which originate from region C have lower backscatter-related Angstrom exponent. This result was also confirmed by columnintegrated data. However, the mean backscatter weighted-altitude of the dust layers according to different scenarios don't differ too much. The overall mean value of the backscatter-weighted altitude was found $3.3 \mathrm{~km}$, with only 0.06 standard deviation among the mean value of the backscatter-weighted altitude according to three region origins (A, B, and C) and two main pathways (Atlantic and Mediterranean). The backscatter-weighted altitude of dust layers originating at regions A, B, and C, is almost similar; 0.29, 0.30 and $0.33 \mathrm{~km}$ a.g.l. respectively.

An interesting aspect of this study is the estimation of the free troposphere (FT) contribution of Saharan dust over Granada. This estimation was done analyzing the mean PBL height during dusty days in August. The mean value of the daily maximal PBL height during this period in Granada, using lidar data 
by the wavelet method (Granados-Muñoz et al., 2012), was about $1.75 \pm 0.11 \mathrm{~km}$ a.g.l. The average base height of dust layers during this period was $1.98 \mathrm{~km}$ a.g.l. This value is higher than the average PBL height during the same period (1.75 km a.g.l.). In the case of the decoupled dust layers, we separate the average values of aerosol optical properties inside dust layers and in the planetary boundary layer. The average top height of dust layers during the same days was $4.86 \mathrm{~km}$. For this purpose, we have investigated $\mathrm{AE}_{355 / 532}$ and $\mathrm{LPDR}_{532}$ profiles in the altitude range 1.75-4.86 km to analyze aerosol properties inside the dust layers in the free troposphere, and in the PBL. Table 4 presents these aerosol optical properties for both cases. Analyses based on the lidar altitude profiles, show that the mean contribution of the free troposphere on AOD over Granada certain periods during August 2012 and 2013 is 0.21 . The mean value of daily $\mathrm{AOD}_{500}$ during the same periods provided by AERONET was 0.37. Thus, the mean free troposphere contribution on $\mathrm{AOD}_{500}$ during the dust events of this month counts on about 58\%. Values of the Table 4 are extracted from the $\mathrm{AE}_{355 / 532}$ and $\mathrm{LPDR}_{532}$ lidar profiles. The lidar measurements reveal the differences between aerosol optical properties inside the PBL and in the free troposphere during these dust events. Anyway, taking into consideration a fixed mean value for the PBL during this month may yield some uncertainness for the values $\mathrm{AE}_{355 / 532}$ and $\mathrm{LPDR}_{532}$ (in PBL and FT) presented in the Table 4. The calculations of these uncertainness for both parameters for the PBL $1.75 \pm 0.11$, result on 0.02 and 0.04 for $\mathrm{AE}_{355 / 532}$ in PBL and FT respectively. These values are quite small compared to the mean values of $\mathrm{AE}_{355 / 532}$ for a fixed PBL height. On the other hand, the uncertainties for the $\mathrm{LPDR}_{532}$ result quite negligible. The differences of the $\mathrm{AE}_{355 / 532}$ and $\mathrm{LPDR}_{532}$ give insights about the dust contribution to these two regions. The values in the Table 4 show that the average backscatter-related Angstrom exponent inside the PBL is about 1.44. This value is well above (2.4 times higher) its average value in the free troposphere. This high value of backscatter-related Angstrom exponent inside the PBL is due to the mixing process among dust particles and anthropogenic contribution. In addition, the average value of the linear particle depolarization ratio inside PBL is 1.53 times lower than in the free troposphere. High differences in the mean values of the $\mathrm{AE}_{355 / 532}$ and $\mathrm{LPDR}_{532}$ indicate that the dust layers are usually decoupled and contribute mainly in the free troposphere than in PBL during the dust intrusions in this period.

Table 4. Angstrom exponent at 355/532 nm $\left(\mathrm{AE}_{355 / 532}\right)$ and linear particle depolarization ratio at $532 \mathrm{~nm}$ $\left(\mathrm{LPDR}_{532}\right)$ of the dust layers calculated in the free troposphere and inside the planetary boundary layer during certain dust events in Granada.

\begin{tabular}{cccccc} 
& \multicolumn{2}{c}{ AE $_{355 / 532}$} & \multicolumn{2}{c}{ LPDR $_{532}$} \\
\cline { 2 - 5 } & \multicolumn{1}{c}{ Average } & St. dev. & Average & St. dev. \\
\hline PBL & 1.44 & 0.19 & 0.15 & 0.01 \\
Free troposphere & 0.60 & 0.21 & 0.23 & 0.02
\end{tabular}

\section{Conclusions}

This paper deals with the analysis of Saharan dust intrusions over the Granada station in the periods JulyAugust, during two successive years, 2012-2013. The focus was set primarily in the determination of 
aerosol optical properties according to different dust intrusion scenarios over Granada. The combination of the data derived from AERONET data with lidar products and the use of HYSPLIT4 backwardtrajectories enabled to give accurate information about the aerosol optical properties of dust intrusions over Granada. Based on these results, there are determined, the principal Saharan dust intrusion scenarios over Granada and then are determined their aerosol optical properties. Cluster analyses of HYSPLIT4 of backward-trajectories were performed to determine the principal dust origins and pathways and consequently the scenarios of dust intrusions over Granada. The final step of these analyses concerns about the classification of the aerosol optical properties according to the different scenarios of dust intrusions over Granada.

During the investigated period, 58 dusty days, grouped into 15 dust events, are identified. The majority of dusty days was identified in August. The number of dusty days per dust event during the whole period was 3.6, with a standard deviation 2.4.

The cluster analysis suggests three origin regions and two pathways of Saharan dust intrusions. Same regions were found also during the previous studies over Granada (Valenzuela, 2012). Almost the same number of dust intrusions coming from the Atlantic (47.3\%) or Mediterranean (52.7\%) pathways is observed over Granada. Meanwhile, the north-west region of the Sahara (region A) is responsible for almost the half of dust intrusions over Granada (47\%) and the other two regions (regions B and C) contribute on about $29 \%$ and $24 \%$ of dust intrusions, respectively. The combination of the origins and the pathways of the air masses which overpass Granada during dust events reveal two principal scenarios; dust intrusions through the Mediterranean, which originate from the region A (35.5\%), and those originating from region B, and come through Atlantic (27\%). The other scenarios, both count only about $37.5 \%$ of all cases.

The distribution frequency of backward trajectories which originate in Sahara regions and end over Granada, suggests that in $71 \%$ of all the cases dust intrusions arrive to Granada in an altitude range 3000 $5000 \mathrm{~m}$. This result is in accordance with other previous studies during the Saharan dust intrusions over the Mediterranean basin (Guerrero-Rascado et al., 2009).

The mean values of $\mathrm{AOD}_{500}$ for the pathways from the Atlantic and Mediterranean are 0.28 and 0.39 respectively. This difference may be due to the presence of additional dust sources in the latter case and the more significant deposition process during the first case. The values of the $\mathrm{AE}_{440-870}$ were 0.57 and 0.43, respectively, for Atlantic and Mediterranean pathways. Meanwhile, the mean AOD $_{500}$ values during the dust intrusions from the three regions were $0.35,0.26$ and 0.41 , respectively, for the regions $\mathrm{A}, \mathrm{B}$, and C. Even though the dust emission rate of region B is higher than the other two regions, due to its larger distance from Granada, its influence on aerosol load over Granada is minor than that of the regions A and C. This evidences the relevance of the transport process against the dust emission rate in the source region. On the other hand, the mean values of $\mathrm{AE}_{440-870}$ at the three regions were $0.52,0.57$ and 0.37 . Thus, the air masses, which come through the Mediterranean, have higher AOD and coarse mode 
contribution to AOD, lower Angstrom exponent and fine mode fraction, compared to the air masses, which come through the Atlantic. Air masses, which originate in region C, have the highest AOD and coarse mode contribution to AOD, and the lowest Angstrom exponent and fine mode fraction. Meanwhile, the air masses, which originate in region B, have the lowest AOD and coarse mode contribution to AOD, and the highest Angstrom exponent and fine mode fraction.

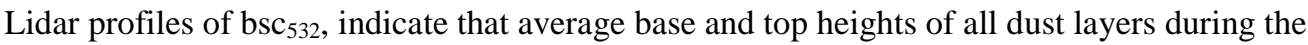
investigation period were 2.1 and $4.8 \mathrm{~km}$. Meanwhile, the average backscatter-weighted altitude and the thickness of dust layers are $3.3 \mathrm{~km}$ and $2.8 \mathrm{~km}$ a.g.l. The $\mathrm{AE}_{355 / 532}$ profiles for the dust intrusions, which originate at regions A and C, and come through the Mediterranean, show very similar patterns. These patterns differ from those of dust intrusions, which originate in region B and come through the Atlantic. The main difference arises from the fact that air masses, which originate from regions $\mathrm{A}$ and $\mathrm{C}$ must overpass the Atlas mountains, influencing more on the formation of decoupled dust layers. Meanwhile, the profiles of $\mathrm{LPDR}_{532}$ were more similar for all scenarios. Due to the mixing processes with fine aerosols. The average $\mathrm{AE}_{355 / 532}$ was lower for the region $\mathrm{C}$ compared to other regions. Meanwhile, the $\mathrm{LPDR}_{532}$ was approximate for all clusters and pathways.

In short, the classification of air masses into several scenarios and the determination of aerosol optical properties according to these scenarios during dust intrusions over Granada in the period July-August, 2012-2013 was performed. The overall results give a clear picture of the optical characteristics of different scenarios of dust intrusions over Granada during this period. Because of the geographical position of Granada in the south of Spain, the analysis of the scenarios of dust intrusions over this site is of the key importance because they provide further insight into the characteristics of Saharan dust intrusions over the whole Iberian Peninsula.

\section{Acknowledgements}

This work was supported by the Andalusia Regional Government through project P12-RNM-2409, by the Spanish Ministry of Economy and Competitiveness through project CGL2013-45410-R and by the European Union's Horizon 2020 Research and Innovation Programme through project ACTRIS-2 (grant agreement No. 654109). The authors thankfully acknowledge the FEDER program for the instrumentation used in this work.

\section{References}

Alados-Arboledas, L., Lyamani, H., Olmo, F.J., 2003. Aerosol size properties at armilla, Granada (Spain). Q. J. Roy. Meteorol. Soc. 129, 1395e1413.

Alados-Arboledas, L., Alcantara, A., Olmo, F.J., Martınez-Lozano, J.A., Estelles, V., Cachorro, V., Silva, A.M., Horvath, H., Gangl, M., D'az, A., Pujadas, M., Lorente, J., Labajo, A., Sorribas, M., Pavese, G., 2008. Aerosol columnar properties retrieved from CIMEL radiometers during VELETA 2002. Atmos. Environ. 42, 2654e2667. Ansmann, A., Bosenberg, J., Chaikovsky, A., Comeron, A., Eckhardt, S., Eixmann, R., Freudenthaler, V., Ginoux, P., Komguem, L., Linne, H., Lopez Marquez, M.A., 
Matthias, V., Mattis, I., Mitev, V., Muller, D., Music, S., Nickovic, S., Pelon, J., Sauvage, L., Sobolewsky, P., Srivastava, M.K., Stohl, A., Torres, O., Vaughan, G., Wandinger, U., Wiegner, M., 2003. Long-range transport of Saharan dust to northern Europe: the 11e16 October 2001 outbreak observed with EARLINET. J. Geophys. Res. 108 (D24), 4783,. http://dx.doi.org/10.1029/2003JD003757.

Ansmann, A., Seifert, P., Tesche, M., Wandinger, U., 2012. Profiling of fine and coarse particle mass: case studies of Saharan dust and Eyjafjallajo€kull/Grimsvo€tn volcanic plumes. Atmos. Chem. Phys. 12, 9399e9415. http://dx.doi.org/10.5194/ acp-12-9399-2012.

Aravind, H., Rajgopal, C., Soman, K.P.A., 2010. Simple approach to clustering in excel. Int. J. Comput. Appl. 11 (7), 0975e8887.

Barnaba, F., Gobbi, G.P., 2004. Aerosol seasonal variability over the Mediterranean region and relative impact of maritime, continental and Saharan dust particles over the basin from MODIS data in the year 2001. Atmos. Chem. Phys. 4, 2367e2391.

Bauer, S., Bierwirth, E., Esselborn, M., Petzold, A., Macke, A., Trautmann, T., Wendisch, M., 2011. Airborne spectral radiation measurements to derive solar radiative forcing of Saharan dust mixed with biomass burning smoke particles. Tellus Ser. B 63, 742e750.

Bosenberg, J., Ansmann, A., Baldasano, J.M., Balis, D., Bockmann, C., Calpini, B., Chaikovsky, A., Flamant, P., Hagard, A., Mitev, V., Papayannis, A., Pelon, J., Resendes, D., Schneider, J., Spinelli, N., Trickl, T., Vaughan, G., Visconti, G., Wiegner, M., 2001. EARLINET: a European aerosol research lidar network, laser remote sensing of the atmosphere. In: Dabas, A., Loth, C., Pelon, J. (Eds.), Selected Papers of the 20th International Laser Radar Conference, 2001. Edition Ecole Polytechnique, Palaiseau, France, pp. 155e158.

Bravo-Aranda, J.A., Navas-Guzma'n, F., Guerrero-Rascado, J.L., Pe'rez-Ramírez, D., GranadosMun Oz, M.J., Alados-Arboledas, L., 2013. Analysis of lidar depolari- zation calibration procedure and application to the atmospheric aerosol char- acterization. Int. J. Remote. Sens. 34, $3543 e 3560$.

Burton, S.P., Ferrare, R.A., Hostetler, C.A., Hair, J.W., Rogers, R.R., Obland, M.D., Butler, C.F., Cook, A.L., Harper, D.B., Froyd, K.D., 2012. Aerosol classification using airborne High Spectral Resolution Lidar measurements e methodology and examples. Atmos. Meas. Tech. 5, 73e98. http://dx.doi.org/10.5194/amt-5-73- 2012.

Cachorro, V.E., Toledano, C., Prats, N., Sorribas, M., Mogo, S., Berjon, A., Torres, B., Rodrigo, R., De la Rosa, J., De Frutos, A.M., 2008. The stronger desert dust in- trusions mixed with smoke over the Iberian Peninsula registered with Sun photometry. J. Geophys. Res. 113, D14S04. http://dx.doi.org/10.1029/ 2007JD009582.

Christensen, J.H., 1997. The Danish Eulerian hemispheric model - a three- dimensional air pollution model used for the Arctic. Atmos.. Env. 31, 4169e4191. Co'rdoba-Jabonero, C.M., Sorribas, J.L., Guerrero-Rascado, J.A., Adame, Herna'ndez, Y., Lyamani, H., Cachorro, V., Gil, M., AladosArboledas, L., Cuevas, E., de la Morena, B., 2011. Synergetic monitoring of Saharan dust plumes and potential impact on surface: a case study of dust transport from Canary Islands to Iberian Peninsula. Atmos. Chem. Phys. 11, 3067e3091.

Cowie, S., Knippertz, P., Marsham, J., 2014. A climatology of dust emission events from northern Africa using long-term surface observations. Atmos. Chem. Phys. 14, 8579e8597.

Dall’Osto, M., Beddows, D., Pey, J., Rodriguez, S., Alastuey, A., Harrison, R., Querol, X., 2012. Urban aerosol size distributions over the Mediterranean city of Barcelona, NE Spain. Atmos. Chem. Phys. 12, $10693 \mathrm{e} 10707$.

Di Sarra, A., Di Iorio, T., Cacciani, M., Fiocco, G., Fua, D., 2001. Saharan dust profiles measured by lidar at Lampedusa. J. Geophys. Res. 106, $10335 \mathrm{e} 10347$.

Draxler, R.R., Rolph, G.D., 2003. HYSPLIT4 Model via NOOA ARL READY Website.NOOA Air Resources Laboratory, Silver Spring MD. 
Eck, T.F., Holben, B.N., Reid, J.S., Dubovik, O., Smirnov, A., O'Neill, N.T., Slutsker, I., Kinne, S., 1999. Wavelength dependence of biomass burning, urban and desert aerosols. J. Geophys. Res. 104 (24), $333 \mathrm{e} 349$.

Engelstaedter, S., Tegen, I., Washington, R., 2006. North African dust emissions and transport. Earth Sci. Rev. 79, 73e100.

Escudero, M., Stein, A., Draxler, R.R., Querol, X., Alastuey, A., Castillo, S., Avila, A., 2006.

Determination of the contribution of northern Africa dust source areas to PM10 concentrations over the central Iberian Peninsula using the Hybrid Sin- gle-Particle Lagrangian Integrated Trajectory model (HYSPLIT) model. J. Geophys. Res. 111, D06210. http://dx.doi.org/10.1029/2005JD006395.

Fernald, F.G., 1984. Analysis of atmospheric lidar observations e some comments.Appl. Opt. 23, $652 \mathrm{e} 653$.

Fernald, F.G., Herman, B.M., Reagan, J.A., 1972. Determination of aerosol height distributions by lidar. J. Appl. Meteorol. 11 (3), 482e489.

Freudenthaler, V., Esselborn, M., Wiegner, M., Heese, B., Tesche, M., Ansmann, A., Muller, D., Althausen, D., Wirth, M., Fix, A., Ehret, G., Knippertz, P., Toledano, C., Gasteiger, J., Garhammer, M., Seefeldner, M., 2009. Depolarization ratio profiling at Several wavelengths in pure saharan dust during SAMUM 2006. Tellus Ser. B Chemical Phys. Meteorolog. 61, $165 \mathrm{e} 179$.

Goudie, A.S., Middleton, N.J., 2001. Saharan dust storms: nature and consequences.Earth Sci. Rev. 56, $179 \mathrm{e} 204$.

Granados-Mun oz, M.J., Navas-Guzma'n, F., Bravo-Aranda, J.A., Guerrero-Rascado, J.L., Lyamani, H., Fern'andez-G'alvez, J., Alados-Arboledas, L., 2012. Automatic determination of the planetary boundary layer height using lidar: one-year analysis over southeastern Spain. J. Geophys. Res. 117, 1e10.

Guerrero-Rascado, J.L., Ruiz, B., Alados-Arboledas, L., 2008. Multi-spectral Lidar characterization of the vertical structure of Saharan dust aerosol over southern Spain. Atmos. Environ. 42 (11), 2668e2681.

Guerrero-Rascado, J.L., Olmo, F.J., Aviles-Rodriguez, I., Navas-Guzman, F., Perez-Ramirez, D., Lyamani, H., Alados Arboledas, L., 2009. Extreme Saharan dust event over the southern Iberian Peninsula in september 2007: active and pas- sive remote sensing from surface and satellite. Atmos. Chem. Phys. 9, 8453e8469.

Hamonou, E., Chazette, P., Balis, D., Papayannis, A., 1999. Characterization of the vertical structure of Saharan dust export to the Mediterranean basin. J. Geophys. Res. 104 (D18), 22257e22270.

Hand, V., Capes, G., Vaughan, D., Formenti, P., Jim, M., Haywood, J., Coe, H., 2010. Evidence of internal mixing of African dust and biomass burning particles by individual particle analysis using electron beam techniques. J. Geophys. Res. 115 (D13301).

Holben, B.N., et al., 1998. AERONETdA federated instrument network and data archive for aerosol characterization. Remote Sens. Environ. 66, 1e16.

IPCC, 2013. Climate Change 2013: the Physical Science Basis. Contribution of Working Group I to the Fifth Assessment Report of the Intergovernmental Panel on Climate Change, 2013.

Israelevich, P.L., Levin, Z., Joseph, J.H., Ganor, E., 2003. Desert aerosol transport in the Mediterranean region as inferred from the TOMS aerosol index. J. Geophys. Res. 107 (D21), 4572.

Kahn, R.A., Gaitley, B.J., Martonchik, J.V., Diner, D.J., Crean, K.A., Holben, B., 2005.

Multiangle Imaging Spectroradiometer (MISR) global aerosol optical depth validation based on 2 years of coincident Aerosol Robotic Network (AERONET) observations. J. Geophys. Res.Atmos. 110, D10s04. http://dx.doi.org/10.1029/ 2004jd004706. 
Kaufman, Y.J., Gitelson, A., Karnieli, A., Ganor, E., Fraser, R.S., Nakajima, T., Mattoo, S., Holben, B.N., 1994. Size distribution and phase function of aerosol particles retrieved from sky brightness measurements. J. Geophys. Res. 99 (10), 341e10 356.

Kaufman, Y.J., Gobbi, G.P., Koren, I., 2006. Aerosol climatology using a tunable spectral variability cloud screening of AERONET data. Geophys. Res. Lett. 33, L07817.

King, M.D., Kaufman, Y.J., Tanre, D., Nakajima, T., 1999. Remote sensing of tropo- spheric aerosols from space: past, present, and future. Bull. Amer. Meteor. Soc. 80, $2229 \mathrm{e} 2259$.

Klett, J.D., 1981. Stable analytical inversion solution for processing lidar returns. Appl. Opt. 20, $211 \mathrm{e} 220$.

Klett, J.D., 1985. Lidar inversion with variable backscatter/extinction ratios. Appl. Opt. 24 (11), $1638 \mathrm{e} 1643$.

Kumar, K.R., Sivakumar, V., Reddy, R.R., Gopal, R.R., Adesina, A.J., 2014a. Identifica- tion and classification of different aerosol types over a subtropical rural site in mpumalanga, South Africa: seasonal variations as retrieved from the AERONET sunphotometer. Aerosol Air Qual. Res. 14, $108 \mathrm{e} 123$.

Kumar, R., Barth, M.C., Madronich, S., Naja, M., Carmichael, G.R., Pfister, G.G.,

Knote, C., Brasseur, G.P., Ojha, N., Sarangi, T., 2014b. Effects of dust aerosols on tropospheric chemistry during a typical pre-monsoon season dust storm in northern India. Atmos. Chem. Phys. 14, $6813 \mathrm{e} 6834$.

Liu, Z., et al., 2008. CALIPSO lidar observations of the optical properties of Saharan dust: a case study of long-range transport. J. Geophys. Res. 113, D07207.

Lyamani, H., Olmo, F.J., Alados-Arboledas, L., 2004. Long-term changes in aerosol radiative properties at Armilla (Spain). Atmos. Environ. 38, 5935e5943.

Lyamani, H., Olmo, F.J., Alados-Arboledas, L., 2005. Saharan dust outbreak over southeastern Spain as detected by sun photometer. Atmos. Environ. 39, 7276e7284.

Lyamani, H., Olmo, F.J., Alcantara, A., Alados-Arboledas, L., 2006a. Atmospheric aerosols during the 2003 heat wave in southeastern Spain II: microphysical columnar properties and radiative forcing. Atmos. Environ. 40, 6465e6476.

Lyamani, H., Olmo, F.J., Alcantara, A., Alados-Arboledas, L., 2006b. Atmospheric aerosols during the 2003 heat wave in southeastern Spain I: spectral optical depth. Atmos. Environ. 40, 6453e6464.

Lyamani, H., Olmo, F.J., Alados-Arboledas, L., 2010. Physical and optical properties of aerosols over an urban location in Spain: seasonal and diurnal variability. Atmos. Chem. Phys. 10, 239e254.

Mathias, V., Balis, D., Boseenberg, J., Eixmann, R., Iarlori, M., Komguem, L., Mattis, I., Papayannis, A., Pappalardo, G., Perrrone, M.R., Wang, X., Matthias, V., et al., 2004b. Vertical aerosol distribution over Europe: statistical analysis of Raman lidar data from 10 EARLINET stations. J. Geophys. Res. 109 (D18201).

Mattis, I., Ansmann, A., Muller, D., Wandinger, U., Althausen, D., 2004. Multiyear aerosol observations with dual-wavelength Raman lidar in the framework of EARLINET. J. Geophys. Res. 109 (D13203).

Miller, K.A., Siscovick, D.S., Sheppard, L., Shepherd, K., Sullivan, J.H., Anderson, G.L., Kaufman, J.D., 2007. Long-term exposure to air pollution and incidence of cardiovascular events in women. N. Engl. J. Med. 356, 447e458. http:// dx.doi.org/10.1056/NEJMoa054409.

Mona, L., Amodeo, A., Pandoolfii, M., Pappalardo, G., 2006. Saharan dust intrusions in the Mediterranean area: three years of Raman lidar measurements. J. Geophy. Res. 111 (D16203). 
Muller, D., Mattis, I., Ansmann, A., Wehner, B., Althausen, D., Wandinger, U., Dubovik, O., 2004. Closure study on optical and microphysical properties of a mixed urban and Arctic haze air mass observed with Raman lidar and Sun photometer. J. Geophys. Res. 109 (D13206).

Navas-Guzm'an, F., Guerrero Rascado, J.L., Alados Arboledas, L., 2011. Retrieval of the lidar overlap function using Raman signals. O' pt. Pura Appl 44, 71e75.

Navas-Guzman, F., Bravo-Aranda, J.A., Guerrero-Rascado, J.L., Granados-Munoz, M.J., AladosArboledas, L., 2013. Statistical analysis of aerosol optical properties retrieved by Raman lidar over Southeastern Spain. Tellus B 65, 21234.

Navaz-Guzman, F.J., 2012. Atmospheric Vertical Profiling by Raman Lidar. PhD Thesis. University of Granada.

Nickovic, S., Kallos, G., Papadopoulos, A., Kakaliagou, O., 2001. A model for predic- tion of desert dust cycle in the atmosphere. J. Geophys. Res. 106 (D16), $18113 \mathrm{e} 18129$.

Papayannis, A., et al., 2008. Systematic lidar observations of Saharan dust over Europe in the frame of EARLINET (2000e2002). J. Geophys. Res. 113 (D10204). Papayannis, A., Mamouri, R.E., Amiridis, V., Kazadzis, S., Pe'rez, C., Tsaknakis, G., Kokkalis, P., Baldasano, J.M., 2009. Systematic lidar observations of Saharan dust layers over Athens, Greece in the frame of EARLINET project (20042006). Ann.Geophys. 27, 3611e3620.

Pappalardo, G., Wandinger, U., Mona, L., Hiebsch, A., Mattis, I., Amodeo, A., Ansmann, A., Seifert, P., Linne, H., Apituley, A., A' lados-Arboledas, L., Balis, D.,

Chaikovsky, A., D'Amico, G., De Tomasi, F., Freudenthaler, V., Giannakaki, E., Giunta, A., Grigorov, I., Iarlori, M., Madonna, F., Mamouri, R.-E., Nasti, L., Papayannis, A., Pietruczuk, A., Pujadas, M., Rizi, V., Rocadenbosch, F., Russo, F., Schnell, F., Spinelli, N., Wang, X., Wiegner, M., 2010. EARLINET correlative measurements for CALIPSO: first intercomparison results. J. Geophys. Res. 115, D00H19. http://dx.doi.org/10.1029/2009JD012147.

Pappalardo, G., Amodeo, A., Apituley, A., Comeron, A., Freudenthaler, V., Linne', H.,

Ansmann, A., Bo€senberg, J., D'Amico, G., Mattis, I., Mona, L., Wandinger, U., Amiridis, V., AladosArboledas, L., Nicolae, D., Wiegner, M., 2014. EARLINET: towards an advanced sustainable European aerosol lidar network. Atmos. Meas. Tech. 7, 2389e2409. http://dx.doi.org/10.5194/amt7-2389-2014.

Perez, C., Nickovic, S., Baldasano, J.M., Sicard, M., Rocadenbosch, F., Cachorro, V.E., 2006. A long Saharan dust event over the western Mediterranean: lidar, Sun photometer observations, and regional dust modeling. J. Geophys. Res. 111, D15214. http://dx.doi.org/10.1029/2005JD006579.

Perez-Ramirez, D., Lyamani, H., Olmo, F.J., Whiteman, D.N., Alados-Arboledas, L., 2012. Columnar aerosol properties from sun-and-star photometry: statistical comparisons and day-to-night dynamic. Atmos. Chem. Phys. 12, 9719e9738.

Pey, J., Querol, X., Alastuey, A., Forastiere, F., Stafoggia, M., 2013. African dust out- breaks over the Mediterranean Basin during 2001e2011: PM10 concentrations, phenomenology and trends, and its relation with synoptic and mesoscale meteorology. Atmos. Chem. Phys. 13, 1395e1410.

Pope, C.A., Burnett, R.T., Thun, M.J., Calle, E.E., Krewski, D., Ito, K., Thurston, G.D., 2002. Lung cancer, cardiopulmonary mortality, and long-term exposure to fine particulate air pollution, JAMA-J. Am. Med. Assoc. 287, 1132e1141. http:// dx.doi.org/10.1001/jama.287.9.1132.

Preißler, J., Wagner, F., Pereira, S.N., Guerrero-Rascado, J.-L., 2011. Multi-instru- mental observation of an exceptionally strong Saharan dust outbreak over Portugal. J. Geophys. Res. 116, D24204. http://dx.doi.org/10.1029/2011JD016527. Prospero, J.M., Ginoux, P., Torres, O., Nicholson, S., Gill, E., 2002. Environmental characterization of global sources of atmospheric soil dust identified with the NIMBUS-7 total ozone mapping spectrometer (TOMS) absorbing aerosol product. Rev. Geophys. 40 (1), 1002. 
Remer, L.A., Kaufman, Y.J., Tanre, D., Mattoo, S., Chu, D.A., Martins, J.V., Li, R.R., Ichoku, C., Levy, R.C., Kleidman, R.G., Eck, T.F., Vermote, E., Holben, B.N., 2005. The MODIS aerosol algorithm, products, and validation. J. Atmos. Sci. 62, 947e973.

Rodriguez, S., Querol, X., Alastuey, A., Kallos, G., Kakaliagou, O., 2001. Saharan dust contributions to PM10 and TSP levels in Southern and Eastern Spain. Atmos. Environ. 35, 2433e2447.

Rodriguez, S., Alastuey, A., Alonso-Perez, S., Querol, X., Cuevas, E., Abreu-Afonso, J., Viana, M., Perez, N., Pandolfi, M., de la Rosa, j, 2011. Transport of desert dust mixed with North African industrial pollutants in the subtropical Saharan Air Layer. Atmos. Chem. Phys. 11, 6663e6685.

Rosenfeld, D., Rudich, Y., Lahav, R., 2001. Desert dust suppressing precipitation: a possible desertification feedback loop. Proc. Natl. Acad. Sci. U. S. A. 98, 5975e5980.

Sassen, K., 2002. Indirect climate forcing over the western US from Asian dust storms. Geophys. Res. Lett. 29 (10), 1465.

Sassen, K., 2005. In: Weitkam, C. (Ed.), Polarization in Lidar, Lidar. Springer Press, New York, pp. $19 \mathrm{e} 42$.

Shao, Y., Wyrwoll, K.-H., Chappel, A., Huang, J., Lin, Z., McTainsh, G., Mikami, M., Tanaka, T., Wang, X., Yoon, S., 2011. Dust cycle: an emerging core theme in earth system science. Aeolian Res. 2, $181 \mathrm{e} 204$.

Sunnu, A., Afeti, G., Resch, F., 2008. A long-term experimental study of the Saharan dust presence in West Africa. Atmos. Res. 87, 13e26.

Tegen, I., Schepanski, K., 2009. The global distribution of mineral dust. IOP Conf. Series. Earth Environ. Sci. 7.

Tesche, M., et al., 2009. Vertical profiling of Saharan dust with Raman lidars and airborne HSRL in southern Morocco during SAMUM. Tellus, Ser. B 61, 144e164. Titos, G., Foyo-Moreno, I., Lyamani, H., Querol, X., Alastuey, A., et al., 2012. Optical properties and chemical composition of aerosol particles at an urban location: an estimation of the aerosol mass scattering and absorption efficiencies.J.

Geophys. Res. Atmos 117 (D04206), 1e12.

Toledano, C., Wiegner, M., Gross, S., Freudethaler, V., Gasteiger, J., Muller, D., Shladitz, A., Weinzierl, B., Torres, B., O'Neill, N.T., 2011. Optical properties of aerosol mixtures derived from sun-sky radiometry during SAMUM-2. Tellus 63B, 635e648.

Valenzuela, A., Olmo, F.J., Lyamani, H., Anto'n, M., Quirantes, A., Alados-Arboledas, L.,

2012a. Analysis of the desert dust radiative properties over Granada using principal plane sky radiances and spheroids retrieval procedure. Atmos. Res. 104e105, $292 \mathrm{e} 301$.

Valenzuela, A., Olmo, F.J., Lyamani, H., Anto'n, M., Quirantes, A., Alados-Arboledas, L.,

2012b. Classification of aerosol radiative properties during African desert dust intrusions over southeastern Spain by cluster origins and cluster analysis. J. Geophys. Res. 117, D06214. http://dx.doi.org/10.1029/2011JD016885.

Valenzuela, A., Olmo, F.J., Lyamani, H., Granados-Mun oz, M.J., Anto'n, M., Guerrero-

Rascado, J.L., Quirantes, A., Toledano, C., Perez-Ramírez, D., Alados-Arboledas, L., 2014. Aerosol transport over the western Mediterranean basin: evidence of the contribution of fine particles to desert dust plumes over Albora'n Island. J. Geophys. Res. Atmos. 119, 14,028e14,044.

Valenzuela, G.A., 2012. African Desert Dust Events Impact over South-eastern Spain (2005-2010): Aerosol Radiative Properties and Forcing. PhD Thesis. Spain, Granada.

Wandinger, U., Ansmann, A., 2002. Experimental determination of the lidar overlap profile with Raman lidar. Appl. Opt. 41, 511e514. 
Wong, M.S., Nichol, J.E., Lee, K.H., 2013. Estimation of aerosol sources and aerosol transport pathways using AERONET clustering and backward trajectories: a case study of Hong Kong. Int. J. Remote Sens. 34 (3), 938e955.

Zuberi, B., Bertram, A.K., Cassa, C.A., Molina, L.T., Molina, M.J., 2002. Heterogeneous nucleation of ice in (NH4)2SO4-H2O particles with mineral dust immersions. Geophys. Res. Lett. 29 (10), 1504. 